\title{
Plant Defense Stimulator Mediated Defense Activation Is Affected by Nitrate Fertilization and Developmental Stage in Arabidopsis thaliana
}

\author{
Camille Verly ${ }^{1,2}$, Atsin Claude Roméo Djoman ${ }^{1,2}$, Martine Rigault' ${ }^{1}$, Frédéric Giraud ${ }^{2}$, \\ Loïc Rajjou ${ }^{1}$, Marie-Emmanuelle Saint-Macary ${ }^{3}$ and Alia Dellagi ${ }^{1 *}$ \\ ${ }^{1}$ Institut Jean-Pierre Bourgin, INRAE, AgroParisTech, Université Paris-Saclay, Versailles, France, ${ }^{2}$ Staphyt-Service \\ L\&G/BIOTEAM, Martillac, France, ${ }^{3}$ Staphyt - BIOTEAM, Marsillargues, France
}

OPEN ACCESS

Edited by:

Paolo Carletti,

University of Padua, Italy

Reviewed by:

Zhonglin Mou,

University of Florida, United States

Dongdong Niu,

Nanjing Agricultural University, China

${ }^{*}$ Correspondence:

Alia Dellagi

alia.dellagi@agroparistech.fr

Specialty section:

This article was submitted to

Crop and Product Physiology,

a section of the journal

Frontiers in Plant Science

Received: 18 October 2019

Accepted: 17 April 2020

Published: 26 May 2020

Citation:

Verly C, Djoman ACR, Rigault M, Giraud F, Rajjou L, Saint-Macary M-E and Dellagi A (2020) Plant Defense

Stimulator Mediated Defense

Activation Is Affected by Nitrate Fertilization and Developmental Stage

in Arabidopsis thaliana.

Front. Plant Sci. 11:583.

doi: 10.3389/fp/s.2020.00583
Plant defense stimulators, used in crop protection, are an attractive option to reduce the use of conventional crop protection products and optimize biocontrol strategies. These products are able to activate plant defenses and thus limit infection by pathogens. However, the effectiveness of these plant defense stimulators remains erratic and is potentially dependent on many agronomic and environmental parameters still unknown or poorly controlled. The developmental stage of the plant as well as its fertilization, and essentially nitrogen nutrition, play major roles in defense establishment in the presence of pathogens or plant defense stimulators. The major nitrogen source used by plants is nitrate. In this study, we investigated the impact of Arabidopsis thaliana plant developmental stage and nitrate nutrition on its capacity to mount immune reactions in response to two plant defense stimulators triggering two major defense pathways, the salicylic acid and the jasmonic acid pathways. We show that optimal nitrate nutrition is needed for effective defense activation and protection against the pathogenic bacteria Dickeya dadantii and Pseudomonas syringae pv. tomato. Using an npr1 defense signaling mutant, we showed that nitrate dependent protection against $D$. dadantii requires a functional NPR1 gene. Our results indicate that the efficacy of plant defense stimulators is strongly affected by nitrate nutrition and the developmental stage. The nitrate dependent efficacy of plant defense stimulators is not only due to a metabolic effect but also invloves NPR1 mediated defense signaling. Plant defense stimulators may have opposite effects on plant resistance to a pathogen. Together, our results indicate that agronomic use of plant defense stimulators must be optimized according to nitrate fertilization and developmental stage.

Keywords: defense (induced), elicitor, Dickeya dadantii, nitrate, developmental stage, Bion, Methyl-jasmonate, Pseudomonas syringae pv. tomato 


\section{INTRODUCTION}

As sessile organisms, plants are exposed to many biotic stresses such as pathogenic microorganisms and herbivores. They have developed the capacity to activate defenses in response to pathogen attacks thus leading to different degrees of resistance which may be effective at the site of infection or systemically (Jones and Dangl, 2006; Wirthmueller et al., 2013; Miller et al., 2017; Alhoraibi et al., 2019; Shine et al., 2019). Complex signaling networks are activated according to the type of invading organism (Bürger and Chory, 2019; Shine et al., 2019; Wang et al., 2020). Defense-related signaling responses involve phosphorylation events, ionic fluxes and accumulation of phytohormones leading to transcriptional activation of genes coding for the synthesis of antimicrobial compounds such as phytoalexins or pathogenesis related (PR) proteins (van Loon et al., 2006; Pieterse et al., 2014; Piasecka et al., 2015; Klessig et al., 2018; Wang et al., 2020).

Salicylic acid (SA) is one of the major hormones involved in plant immunity and was described as being mainly involved in plant protection against biotrophic or hemibiotrophic pathogens (Pieterse and Van Loon, 1999; Glazebrook, 2005; Zhang and Li, 2019). Defense genes activated by SA include PR5, encoding a thaumatin-like protein and $P R 1$, encoding an antimicrobial protein with sterol binding and peptide signaling functions (Uknes et al., 1992; Chen et al., 2014; Gamir et al., 2017). Jasmonic acid (JA) and ethylene (ET) were reported to be involved in plant protection against necrotrophic pathogens (Pieterse and Van Loon, 1999; Glazebrook, 2005; Mengiste, 2012) and may be induced by non-pathogenic plant growth promoting rhizobacteria (PGPR) (Backer et al., 2018). JA/ET-dependent responses promote activities of peroxidases, polyphenol oxidases and lipoxygenases (Van Wees et al., 1999; Ruan et al., 2019). Genes encoding the defensin PDF1.2 and the lipoxygenase LOX2, are widely used as markers of the JA/ET defense pathway (Manners et al., 1998; Thomma et al., 1998; Yang et al., 2019). The JA pathway, with $L O X 2$ as a marker gene, is effective against insect pests (Glauser et al., 2009).

Several reports indicate the existence of cross-talks between those defense signaling pathways (Pieterse et al., 2011; Thaler et al., 2012; Vos et al., 2015; Bürger and Chory, 2019; Yang et al., 2019). An antagonism was generally described between SA dependent defenses and JA/ET dependent defenses (Koornneef and Pieterse, 2008; Leon-Reyes et al., 2010; Van der Does et al., 2013; Caarls et al., 2017; Li et al., 2019; Yang et al., 2019). The mechanisms underlying this antagonism imply transcriptional regulations involving transcription factors such as WRKY70 and ROXY19 (Li et al., 2004, 2019; Ndamukong et al., 2007; Caarls et al., 2015). Interestingly, synergism between SA and JA pathways was also described (Mur et al., 2006; Liu et al., 2016).

The NON-EXPRESSOR OF PATHOGENESIS-RELATED GENES 1 protein (NPR1) (Cao et al., 1997; Mou et al., 2003; Durrant and Dong, 2004) is a key defense regulator, known to be involved in both SA and JA/ET signaling pathways (Pieterse and Van Loon, 2004; Withers and Dong, 2017; Barker, 2018; Backer et al., 2019). Its role in SA defense signaling has been well-studied and described. NPR1 binds SA (Wu et al., 2012;
Manohar et al., 2015) and is thought to be a co-receptor with two other proteins NPR3 and NPR4 which also bind SA and act as transcriptional repressors of the SA response (Kuai et al., 2015; Withers and Dong, 2016; Ding et al., 2018). Following SA perception, NPR1 binds to TGA transcription factors leading to the transcription of PR genes (Després et al., 2000; Kinkema et al., 2000; Zhou et al., 2000; Chern et al., 2001; Kuai et al., 2015). The mechanism by which NPR1 is involved in JA/ET defenses remains unclear. An A. thaliana nprl mutant plant fails to induce $P R$ gene expression in response to $S A$, while NPR1 overexpression leads to an up-regulation of the $P R$ genes and enhanced disease resistance (Cao et al., 1998). NPR1 is also involved in the activation of JA/ET dependent defenses but probably via an alternate mechanism. An A. thaliana nprl mutant is unable to activate the JA/ET dependent defenses in response to PGPR (Koornneef and Pieterse, 2008; Nie et al., 2017). Overexpressing engineered forms of NPR1 retained in the plant cytosol results in the suppression of JA signaling (Spoel et al., 2003, 2007; Yuan et al., 2007) indicating that the antagonistic effect of SA over JA signaling requires cytosolic NPR1. Spoel et al. (2003) suggested a cytoplasmic role of NPR1 in the cross-talk between JA/ET and SA defense pathways.

Different environmental conditions may influence plant pathogen interactions such as the type of light (Kazan and Manners, 2011; De Wit et al., 2013; Janda et al., 2015; Mintoff et al., 2015) mineral nutrition (Poschenrieder et al., 2006; Walters et al., 2007; Fagard et al., 2014; Aznar et al., 2015) or water availability (Nejat and Mantri, 2017). The impact of fertilizers, in particular nitrogen fertilization, on plant-pathogen interactions is well-documented however, the underlying mechanisms remain unclear (Shaner and Finney, 1977; Eyles et al., 2007; Pato and Obeso, 2013; Veresoglou et al., 2013; Fagard et al., 2014; Mur et al., 2017; Sun et al., 2020).

Nitrogen is present in the form of $\mathrm{NO}_{3}^{-}, \mathrm{NH}_{4}^{+}$or amino acids, the availability of which depends on physical factors such as $\mathrm{pH}$ and temperature. Plants adapted to acidic $\mathrm{pH}$ tend to take up $\mathrm{NH}_{4}^{+}$or amino-acids and plants adapted to higher $\mathrm{pH}$ and aerobic soils (which is the case of most arable lands) tend to prefer $\mathrm{NO}_{3}^{-}$(Masclaux-Daubresse et al., 2010). Nitrate is taken up at the root level by two different types of transport systems (Krapp et al., 2014; Wang et al., 2018): (1) a high affinity system involving the NRT1/NPF (nitrate transporter 1/peptide transporter family) family of transporters, (2) a low affinity system involving the NRT2 family of transporters. Following uptake, $\mathrm{NO}_{3}^{-}$is reduced to $\mathrm{NO}_{2}^{-}$by a cytosolic nitrate reductase, and then $\mathrm{NO}_{2}^{-}$is further reduced by a plastidial nitrite reductase into $\mathrm{NH}_{4}^{+}$(Masclaux-Daubresse et al., 2010). Ammonium is incorporated into amino acids in plastids via glutamate synthase (GS)/glutamine-2-oxoglutarateaminotransferase (GOGAT) cycle (Masclaux-Daubresse et al., 2010; Krapp et al., 2014; Wang et al., 2018). Nitrogen fertilization has been a major factor in improving crop productivity in the last decades (Hirel et al., 2007; Wang et al., 2018) but may increase disease impact depending on the considered pathosystem (Fagard et al., 2014; Mur et al., 2017; Sun et al., 2020). A better understanding of the mechanisms by which nutrient elements 
influence plant defenses may be useful to improve cultural practices in order to optimize fertilization and reduce pesticide use thus decreasing the environmental impact of agriculture.

Emerging new plant protection strategies based on the exploitation of the capacity of plants to mount efficient immune responses are widely explored and are expected to allow the reduction of pesticide use (Ramamoorthy et al., 2001; Heil and Bostock, 2002; Bektas and Eulgem, 2015). These strategies rely on the use of plant defense stimulators which trigger plant defenses before or upon pathogen attack. Such plant defense stimulators include Bion ${ }^{\circledR}$ which contains the bioactive molecule S-acibenzolar-S-Methyl activating the SA dependent defense pathway and is used in agriculture to protect tomato or apple against pathogens. However the effectiveness of plant defense stimulators in the field remains uncertain and may depend on different internal and/or external factors such as the plant developmental stage, temperature, drought, and/or mineral nutrition (Walters et al., 2007; Steimetz et al., 2012; Carella et al., 2015).

Our work addresses the combined impacts of the plant developmental stage and nitrogen nutrition on the efficiency of plant response to plant defense stimulators. We show that plant response to plant defense stimulators depends on both developmental stage and nitrogen nutrition with a stronger effect of nutrition.

\section{MATERIALS AND METHODS}

\section{Plant Material and Growth Conditions}

Seeds of Arabidopsis thaliana Col-0 WT accession were obtained from Versailles Arabidopsis Stock Center (INRA Versailles France) and seeds of npr1-1 mutant (N3726) in Col-0 WT background (Cao et al., 1997) were obtained from NASC ${ }^{1}$. Seeds were sown in unfertilized soil with different nitrate fertilization conditions 2, 10, and $26 \mathrm{mM}$ of nitrate (Supplementary Table 1), in a growth chamber under the following conditions; $18 \mathrm{~h}$ of light $21^{\circ} \mathrm{C}, 6 \mathrm{~h}$ of dark $19^{\circ} \mathrm{C}, 70 \%$ relative humidity). Plants were grown until four different stages: Stage 1: plantlet (2 weeks after sowing (A.S.), Stage 2: vegetative stage (3 weeks A.S.), Stage 3: floral induction (4 weeks A.S.), Stage 4: flowering time (5 weeks A.S.).

\section{Nitrate Content Quantification}

Leaves were harvested $48 \mathrm{~h}$ after treatment and immediately crushed in liquid nitrogen then stored at $-80^{\circ} \mathrm{C}$. Nitrate content is measured by a spectrophotometric method by comparison with a $\mathrm{NaNO}_{3}$ scale (Miranda et al., 2001). Ten milligrammes of frozen leaf powder were incubated in $300 \mu \mathrm{L}$ of sterile distilled water during $20 \mathrm{~min}$ on ice. Samples were centrifuged at $15,000 \mathrm{rpm}$ at $4^{\circ} \mathrm{C}$ during $20 \mathrm{~min}$ and supernatant was harvest twice. Ten microliters of supernatant were mixed with $90 \mu \mathrm{L}$ of water and $100 \mu \mathrm{L}$ of Miranda reagent $(0.5 \mathrm{M} \mathrm{HCl}, 0.25 \%$ Vanadium chloride, $0.005 \% \mathrm{~N}-1$ naphtyethylendiamin, $0.1 \%$ Sulfanilamide) and incubated during

${ }^{1}$ http://www.arabidopsis.info
$2 \mathrm{~h}$ at $60^{\circ} \mathrm{C}$. Concentration of nitrate was then calculated based on a standard curve obtained with $\mathrm{NaNO}_{3}$ standard solutions by spectrophotometry at $540 \mathrm{~nm}$. For each experiment 20 rosettes were used.

\section{Amino Acid Quantification}

Amino acid content was measured by a spectrophotometric method adapted from Rosen (1957). Amino acids were extracted by vortexing $150 \mathrm{mg}$ of frozen leaf powder with $1 \mathrm{~mL}$ of $2 \% 5$-sulfosalicylic acid (w/v in water). Samples were then centrifuged at 13,000 rpm during $10 \mathrm{~min}$ and supernatant was harvested for the following steps. Fifty microliters of samples were mixed with $150 \mu \mathrm{L}$ of water, $100 \mu \mathrm{L}$ of cyanide acetate solution $(0.2 \mathrm{~mL}$ of $10 \mathrm{mM} \mathrm{KCN}, 9.8 \mathrm{~mL}$ of $2.65 \mathrm{M}$ sodium acetate, $8 \%$ acetic acid $\mathrm{pH}$ 5.35) and $100 \mu \mathrm{l}$ of ninhydrine solution (3\% ninhydride in Ethylene glycol monomethylether) then incubated during $15 \mathrm{~min}$ at $100^{\circ} \mathrm{C}$ under fume hood, before adding $1 \mathrm{~mL}$ of $50 \%$ isopropanol. Samples were placed on ice to decrease temperature to room temperature. Two hundred microliters of samples were used to quantify amino acid content by comparison with standard solutions of L-glutamine by spectrophotometry at $570 \mathrm{~nm}$. For each experiment 20 rosettes were used.

\section{RNA Extraction and cDNA Synthesis}

RNA extraction and cDNA synthesis were performed as described in Aznar et al. (2014). For each experiment 6 to 10 plants were used.

\section{Quantitative PCR}

Quantitative PCR reactions were carried out in $10 \mu \mathrm{L}$, with $5 \mu \mathrm{L}$ of SybrGreen ${ }^{\circledR}$ (Bio-Rad, Hercules, CA, United States) mix, $0.3 \mu \mathrm{M}$ of each primer, and $2.5 \mu \mathrm{L}$ of cDNA. Quantitative PCRs were carried out using a CFX-96 Real Time PCR system thermal cycler (Bio-Rad, Hercules, CA, United States). The raw data obtained were processed using the CFX manager software (Bio-Rad, Hercules, CA, United States). For each analysis, a cycle threshold (Ct) value was extracted and then transformed into Starting Quantity (SQ) values based on a standard curve equation. Consequently, for each condition, since PCRs were performed in triplicate, 3 SQ values were obtained for each sample and then averaged (geometric mean of SQ values). The geometric mean of the SQ values obtained for each gene of interest was then divided by the geometric mean of SQ values obtained for the reference gene. Normalized transcript level was then obtained and expressed as arbitrary units. Clathrin was used as a reference gene because it was stably expressed under the different stages and the different nutritional conditions. Experiments were performed three times with similar results. Representative data are shown.

\section{Plant Treatment With Plant Defense Stimulators}

In all experiments, plants were kept under cover $24 \mathrm{~h}$ before plant defense stimulator treatment. Then, plants were sprayed with 
methyl-jasmonate (at $0.1 \mathrm{mM}$ with $0.5 \% \mathrm{DMSO}$ ); the commercial plant defense stimulator Bion ${ }^{\circledR}$ (at $0.015 \%$ in water w/v), or water. The Bion ${ }^{\circledR}$ concentration was determined based on a calculation starting from the recommended dose for its agronomic use. The recommended Bion ${ }^{\circledR}$, dose for tomato in the field $(0.05 \mathrm{~kg} / \mathrm{ha})$ and was adapted in volume concentration $(\mathrm{g} / \mathrm{L})$ considering a field spray at $330 \mathrm{~L} / \mathrm{ha}$, this corresponds to a $0.015 \%$ in water $\mathrm{w} / \mathrm{v}$ Bion ${ }^{\circledR}$ solution. Spraying of the different elcicitors was performed separately to avoid cross contamination. Plants were kept under cover and grown in the same growth chamber. For each plant defense stimulator treatment, they were kept in separate boxes. Plants were then harvested 24 or $48 \mathrm{~h}$ following treatment, frozen in liquid nitrogen in order to extract RNA and amplify genes by qRT-PCR. For protection assays, plants were inoculated with the pathogenic bacteria as indicated below $48 \mathrm{~h}$ following plant defense stimulator treatments.

\section{Bacterial Strains and Inoculation Method}

The Dickeya dadantii 3937 strain was obtained from our own collection. Bacteria were grown in Luria-Bertani medium. Forty-eight hours following water or plant defense stimulator treatment, bacterial inoculation was performed. For plant inoculation, a bacterial suspension at an OD600 of $0.1\left(10^{8}\right.$ C.F.U./mL) made up in $50 \mathrm{mM}$ potassium phosphate buffer $(\mathrm{pH}$ 7) was used. Plants were covered during the whole assay to obtain saturating humidity and facilitate infection. To inoculate plants, a small hole was made with a needle in the leaf, and then, $5 \mu \mathrm{L}$ of a bacterial suspension was deposited on the hole. In each experiment, 16 plants were inoculated for each condition and two leaves per plant were inoculated.

Disease severity levels were then scored $48 \mathrm{~h}$ post-inoculation (p.i) identified as the best timing for comparing disease severity (Rigault et al., 2017). The proportion of macerated surface in each inoculated leaf was calculated. The surface of the maceretad lesion and the surface of the corresponding leaves were measured using the open source software ImageJ https://imagej.nih.gov/ij/. This allowed calculating an average of lesion surfaces (in $\mathrm{cm}^{2}$ ) and an average of proportion of macerated surface for each leaf.

The Pseudomonas syringae pv. tomato DC3000 bacterial strain was from our own stock. Forty-eight hours following plant defense stimulator treatment, plants were sprayed with a bacterial suspension at a concentration of $5 \times 10^{7} \mathrm{cfu} \mathrm{mL}^{-1}$ in sterile water containing $0.01 \%$ Silwett. In planta bacterial populations were monitored $48 \mathrm{~h}$ after inoculation. Leaves were harvested then bacterial numbering was performed by tissue grinding followed by serial dilutions plated on King B medium with $60 \mu \mathrm{g} / \mathrm{mL}$ Rifampicin (King et al., 1954).

For each experiment 6 to 8 plants were used and 3 to 4 leaves were harvested or scored. This allowed us to analyze at least 20 leaves for each experiment.

\section{Statistical Analysis}

All experiments were performed in three to four independent biological replicate. The size of all the samples is indicated in the figure legends. EXCEL-STAT plugin was used to perform statistical analysis on data.

\section{RESULTS}

\section{Plant Growth Modifications Under Different Nitrate Fertilization Conditions}

The objective of this work was to evaluate both the effect of nitrogen nutrition and the developmental stage on defense activation by plant defense stimulators. For this purpose, different growth conditions in terms of nitrate supply and plant age were considered. In order to study the effect of developmental stages on defense activation in Arabidopsis, four developmental stages were considered based on the physiological steps representing four key phases in A. thaliana life cycle described in Boyes et al. (2001). In order to study the effect of nitrate nutrition, we chose to study three different levels: (1) limitation, (2) optimal fertilization, and (3) over-fertilization. In order to determine the nitrate concentrations required for these three physiological conditions, the following criteria were considered. A previous work on Arabidopsis nitrogen metabolism showed a differential accumulation of nitrogen related metabolites as well as enzymatic activities in plants cultivated under 2 and $10 \mathrm{mM}$ nitrate (Lemaître et al., 2008). Plants grown under $10 \mathrm{mM}$ nitrate displayed better growth than those grown under $2 \mathrm{mM}$ nitrate (Loudet et al., 2003; Lemaître et al., 2008). Based on these data, the nitrate limitation nutrition used in the present study, was $2 \mathrm{mM}$ nitrate. For the optimal growth conditions, in the present study, we used the $10 \mathrm{mM}$ nitrate. Although, under agronomic conditions over-fertilization occurs quite regularly, it is unclear how over fertilization can affect plant defenses. To address this question, we determined a nitrate level higher than $10 \mathrm{mM}$, resulting in a reduced plant growth without being lethal or affecting too much plant development. For this purpose, plants grown under 20, 26, and $50 \mathrm{mM}$ nitrate were tested. The $26 \mathrm{mM}$ nitrate concentration slightly affected Arabidopsis growth (Figure 1) without being lethal; while $20 \mathrm{mM}$ did not significantly affect plant growth and $50 \mathrm{mM}$ was toxic (data not shown). To confirm that the three nitrate fertilization conditions have different impacts on plant physiology and/or development under the three growth conditions, we determined the impact of nitrate nutrition on some physiological and/or metabolic traits (Figure 1). Nitrate and amino acid contents were monitored. Plant growth was quantified via the number of leaves per plant and the projected rosette surface. Plants grown under limiting nitrate levels $(2 \mathrm{mM})$ displayed lower nitrate, amino acid and reduced leaf number and rosette surface at stage 2 to stage 4 . This indicates that the lower nitrate $2 \mathrm{mM}$ supply has an impact on plant nitrogen metabolism that can be observed starting from the stage 2 . Although growing plants under $26 \mathrm{mM}$ nitrate did not result in an increase in nitrate or amino acid content, the number of leaves (stage 4) and the projected rosette area (stage 3) were affected compared to those grown under $10 \mathrm{mM}$ nitrate (Figure 1). This indicates that $26 \mathrm{mM}$ nitrate supply has a negative impact on plant development which can be observed starting from stage 3 .

Together these data indicate that the three nutritional regimes impacted differently the plant physiological status and nitrogen metabolism. The $2 \mathrm{mM}$ nitrate nutritional condition is limiting 

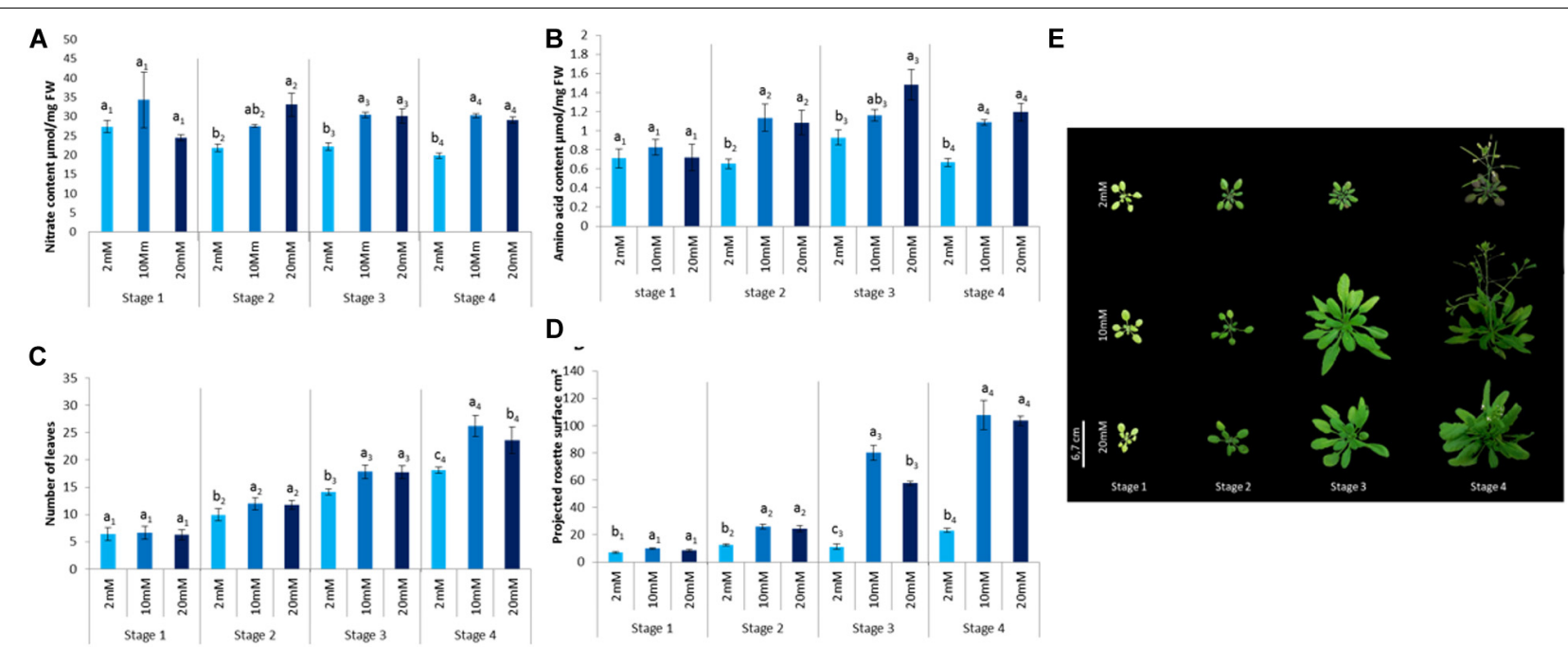

FIGURE 1 | Impact of different nitrate fertilization levels on Arabidopsis thaliana physiological traits. Plants were cultivated until the indicated developmental stages (four stages) under the indicated nutritional conditions (2, 10, 26 mM). (A) Total nitrate content was quantified in healthy plants. (B) Total amino acid content was quantified. (C) Number of leaves per plant. (D) Projected rosette surface. (E) Picture of representative plants cultivated under indicated levels of nitrate at indicated developmental stages. $N=20$. Error bars represent standard deviation. Letters indicate similarities or differences based on a $t$-test performed to compare samples of the same stage $(p<0.05)$. Experiments were performed three times with similar results. Representative data are shown.

and $26 \mathrm{mM}$ nitrate nutritional condition corresponds to an over-fertilization, while $10 \mathrm{mM}$ nitrate corresponds to an optimal nitrate supply.

\section{Plant Developmental Stage Affects the Capacity to Activate Defense Gene Expression in Response to Plant Defense Stimulators}

During the different phases of plant development, important metabolic and transcriptomic changes occur which may affect basal defenses and activation of immune responses. These modifications could account for the variability of plant defense stimulator activity under agronomic conditions. To address this point, Arabidopsis plants were grown until the four developmental stages considered as key steps in Arabidopsis life cycle (Boyes et al., 2001). Three nitrate fertilization levels were applied $(2,10$, and $26 \mathrm{mM})$. Plants were treated with either MeJA, which is known to activate the JA/ET defense pathway, or with Bion ${ }^{\circledR}$, which is known to activate the SA pathway. Expression profiles of two marker genes of the SA pathway (PR1 and PR5) and two marker genes of the JA/ET pathway (LOX2 and PDF1.2) were monitored by qRT-PCR. To determine the time post-plant defense stimulator treatment the most relevant to monitor defense gene expression, plants were collected 24 and $48 \mathrm{~h}$ following Bion ${ }^{\circledR}$ treatment at the four developmental stages and under 2 and $10 \mathrm{mM}$ nitrate nutritional conditions. These experiments showed that the highest level of gene expression was reached $48 \mathrm{~h}$ after treatment (Supplementary Figure 1). Thus, the rest of the experiments were performed by analyzing gene expression $48 \mathrm{~h}$ after plant defense stimulator treatment. In order to determine the effect of the plant developmental stage on defense gene expression, normalized transcript levels were compared under each treatment and each nitrate nutrition separately (Figure 2). Figure 2 shows that plant developmental stage significantly affects most of the defense responses. Basal defenses are significantly affected by developmental stage as indicated by the expression profiles of the four marker genes in control pants (Figures 2A-D). The effect of developmental stage on defense activation by plant defense stimulators is significant under the three nutritional conditions. Interestingly, nitrate supply impacts the effect of stage on defense activation (Figure 2 and Supplementary Figures 2, 3). For example, at $2 \mathrm{mM}$ nitrate supply, $P R 1$ and PR5 transcript levels in response to Bion ${ }^{\circledR}$ are significantly reduced at stage 4 compared to other stages, while at $10 \mathrm{mM}$ nitrate supply $P R 1$ and $P R 5$ transcript levels are globally high at all stages. Although the transcript level of PR1 and PR5 are low following MeJA treatment, they accumulate differentially depending on the developmental stage when plants are grown under $10 \mathrm{mM}$ nitrate. There is no stage effect on PR1 and PR5 transcript levels in response to MeJA under limiting nitrate or over-fertilization. The transcript levels of the two JA/ET markers genes PDF1.2 and LOX2 are affected by the developmental stage whatever the nitrate nutrition. These two markers are more highly expressed at stage 2 following MeJA treatment under 2 and $10 \mathrm{mM}$ nitrate, compared to the other stages. Together these data indicate that depending on the nutrition, developmental stage plays crucial role in the plant defense system.

\section{Nitrate Fertilization Affects Plant Capacity to Activate Defense Gene Expression in Response to Plant Defense Stimulators}

To determine whether nitrate fertilization affects defense activation, plants were treated with either MeJA or with Bion ${ }^{\circledast}$ 


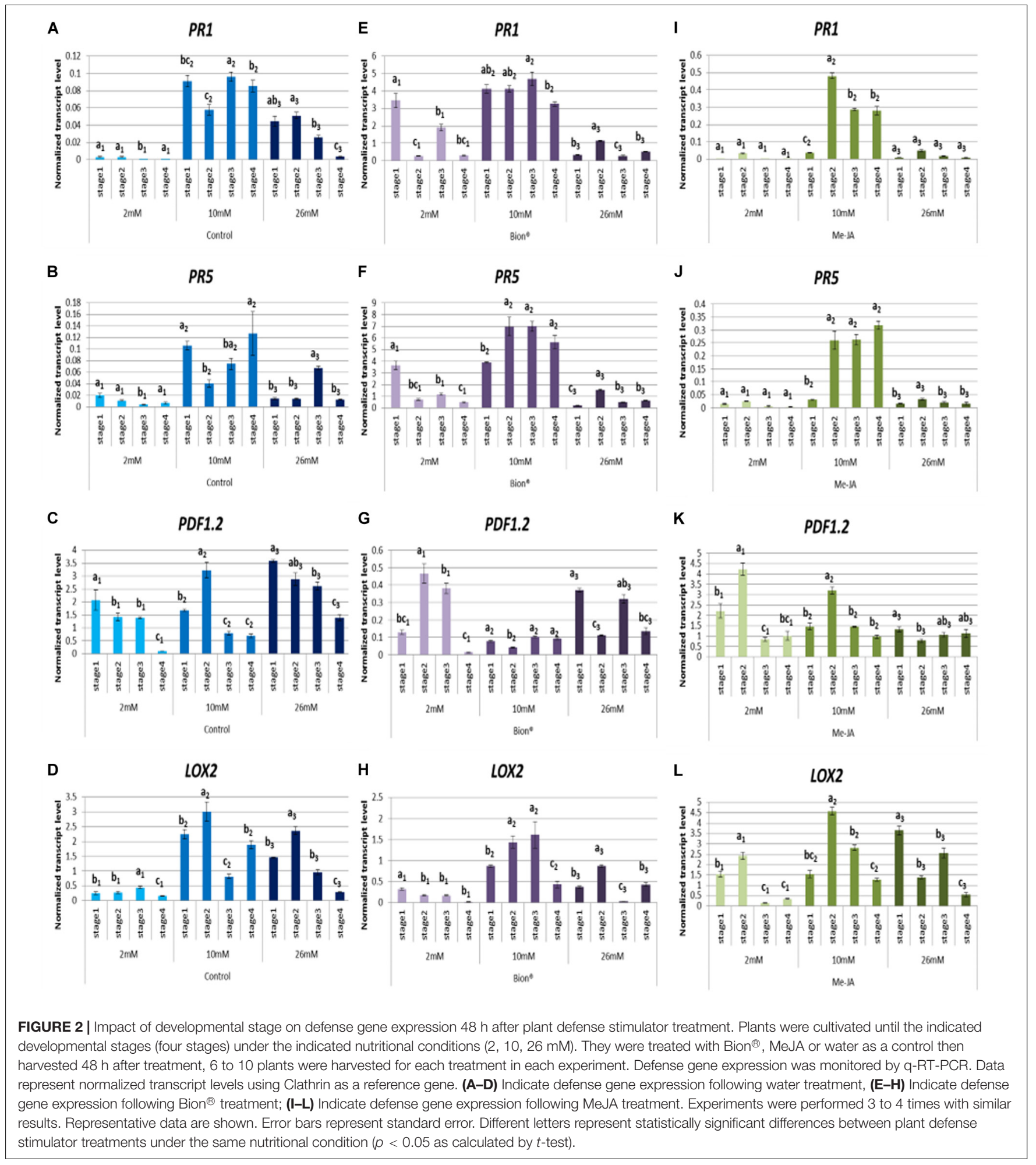

and expression profiles of two maker genes of the SA pathway (PR1 and PR5) and two marker genes of the JA/ET pathway (LOX2 and PDF1.2) were monitored by qRT-PCR $48 \mathrm{~h}$ after plant defense stimulator treatment (Figure 3). Figure 3 shows that nitrate nutrition significantly affects most of the defense responses. Basal defenses are in most cases significantly affected by nitrate as indicated by the expression profiles of the four marker genes in control pants (Figure 3). At all developmental stages, nitrate supply significantly affected the expression of the SA markers following Bion ${ }^{\circledR}$ treatment and the highest expression 
of these markers was obtained under $10 \mathrm{mM}$ nitrate. Nitrate supply significantly affected the expression levels of the JA/ET defense markers following MeJA treatment. Interestingly, Bion ${ }^{\circledR}$ treatment results in the down regulation of PDF1.2 and LOX2 genes under all nitrate treatments (Supplementary Figures 2, 3).

Together these data indicate that plant defense stimulator mediated defense gene activation depends both on the stage and on nitrate nutritional condition.

\section{Nitrate Supply Affects Plant Defense Stimulator Mediated Protection Against Dickeya dadantii and Pseudomonas syringae pv. tomato}

The enterobacterium $D$. dadantii is a necrotrophic plant pathogen able to infect $A$. thaliana plants causing maceration symptoms as a results of the secretion of large amounts of plant cell degrading enzymes (Reverchon and Nasser, 2013). The model plant $A$. thaliana, in turn, activates different defenses to limit infection, such as the JA/ET defense pathway and the accumulation of reactive oxygen species (Fagard et al., 2007). The Gram negative bacterium $P$. syringae pv. tomato is a model plant pathogen (Xin and He, 2013). The SA signaling pathway is known to promote Arabidopsis defense against $P$. syringae pv. tomato and it is commonly used to monitor plant defense stimulator activities (McCann et al., 2012; Rufián et al., 2019). To know whether nitrate fertilization may influence the plant defense stimulators mediated protection, we decided to use plants at vegetative stage (stage 2 ). Indeed, at stage 2, differential expression profiles of defense genes were observed in response to Bion $^{\circledR}$ and MeJA allowing a better interpretation of the putative connection between protection and defenses. In addition, this stage is commonly used in most studies, allowing a better interpretation of the data compared to the literature (Rufián et al., 2019). Two days after plant defense stimulator or water treatment, plants were inoculated with $P$. syringae pv. tomato or D. dadantii.

To know whether nitrate supply affects $A$. thaliana defenses against $P$. syringae pv. tomato, bacterial populations were monitored in control plants and compared with Bion ${ }^{\circledR}$ or MeJA treated plants under the three nitrate supply conditions. Symptoms caused by $P$. syringae pv. tomato can be seen in Supplementary Figure 5. Nitrate limitation $(2 \mathrm{mM})$ resulted in reduced plant susceptibility to $P$. syringae pv. tomato in control plants, indicating that basal defenses against $P$. syringae pv. tomato are more efficient in nitrate starved plants than in optimally or over-fertilized plant (Figure 4A). Bion ${ }^{\circledR}$ treatment resulted in plant protection under 2 and $10 \mathrm{mM}$ nitrate supply but was inefficient on over-fertilized plants. Interestingly, over-fertilization resulted in enhanced plant susceptibility to P. syringae pv. tomato following MeJA treatment (Figure 4B).

To know whether nitrate supply affects basal $A$. thaliana susceptibility to the $D$. dadantii, symptom severity on water treated control plants were compared under the three nitrate supply conditions. The level of nitrate fertilization had no effect on the proportion of macerated leaf surface in non-elicited plants (Figure 5A). Following MeJA treatment, the proportion of leaf macerated surface was decreased under optimal nitrate supply $(10 \mathrm{mM})$, but no effect of MeJA was observed when plants were under-fertilized or over-fertilized (Figures 3B,D and Supplementary Figure 4). These data indicate that MeJA is efficient to protect $A$. thaliana against $D$. dadantii under optimal nitrate supply only. The proportion of leaf macerated surface was increased following Bion ${ }^{\circledR}$ treatment under $2 \mathrm{mM}$ nitrate fertilization but unaffected by Bion ${ }^{\circledR}$ under 10 or $26 \mathrm{mM}$ nitrate nutritional conditions.

These data indicate that the level of nitrate fertilization influences the capacity of the plant to activate efficient defenses following plant defense stimulator treatments against necrotrophic pathogens such as $D$. dadantii and hemibiotrophic pathogens such as $P$. syringae pv. tomato.

\section{NPR1 Gene Is Involved in Nitrate Dependent Plant Defense Stimulator Mediated Defense Responses}

As a key player in plant immunity, NPR1 was shown to be involved in both SA and JA/ET signaling pathways (Spoel et al., 2003; Pieterse and Van Loon, 2004; Mao et al., 2007). We investigated whether nitrate supply affected susceptibility of the npr1-1 mutant to $D$. dadantii. For this purpose, symptom severity on Col-0 WT plants were compared to that of npr1-1 mutant in water treated control plants under the three nitrate supply conditions. Over-fertilization and under-fertilization increased npr1-1 mutant susceptibility compared to WT (Figure 5A) indicating that NPR1 is required for the plant basal defense against $D$. dadantii. Plant defense stimulators activity was monitored in the npr1-1 mutant background to know whether NPR1 was involved in the plant response to plant defense stimulators under the different nitrate nutritional conditions. Interestingly, both plant defense stimulator treatments failed to show any effect on plant disease severity in the npr 1-1 mutant whatever the level of fertilization used (Figure 5B). Thus, while we observed on WT plants an impact of Bion ${ }^{\circledR}$ and MeJA on plant protection against $D$. dadantii, no effect was observed on the npr1-1 mutant plants.

These data suggest that nitrate dependent defense activation by plant defense stimulators requires a functional plant defense signaling machinery which likely involves NPR1.

To investigate whether the role of NPR1 in protection against $D$. dadantii following MeJA treatment and increased susceptibility to $D$. dadantii following Bion ${ }^{\circledR}$ treatment would involve the SA and/or the ET/JA, defense gene expression was monitored in the npr1-1 mutant and compared to their expression in the Col-0 WT. For this purpose, npr1-1 mutant plants were grown until stage 2 under 2, 10, or $26 \mathrm{mM}$, treated with water (control), Bion ${ }^{\circledR}$ or MeJA and transcript levels of defense genes were monitored by qRT-PCR. Figures 6A,B indicates that, as expected, the expression level of the two SA markers genes PR1 and PR5 is drastically reduced in the npr11 mutant compared to Col-0 WT. The expression profiles of LOX2 was similar in Col-0 WT and npr1-1 under the nutrition conditions of 2 and $10 \mathrm{mM}$ nitrate. Interestingly, the LOX2 transcript level was globally lower in $n p r 1-1$ plants under $26 \mathrm{mM}$ 
A

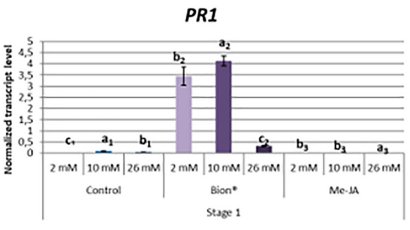

B

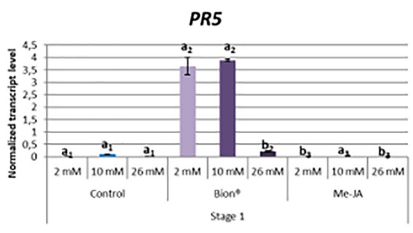

C

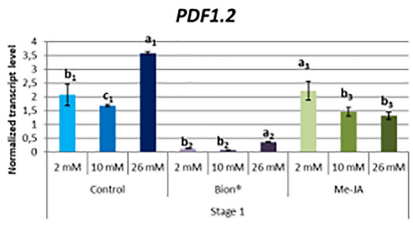

D

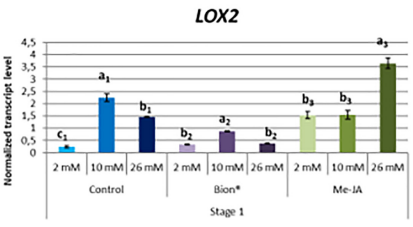

I

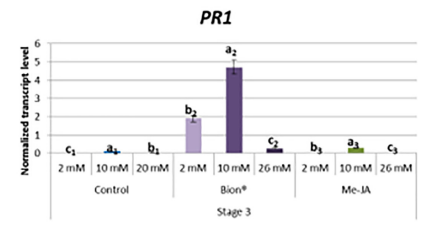

J

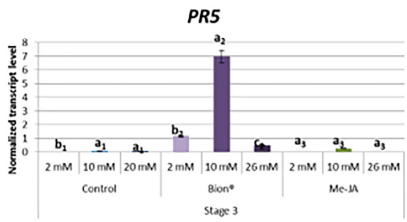

K

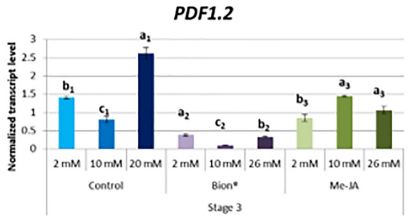

L

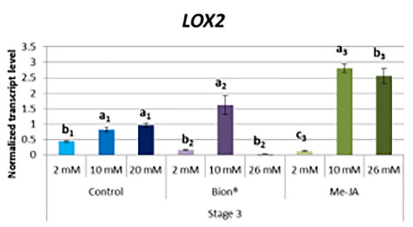

E

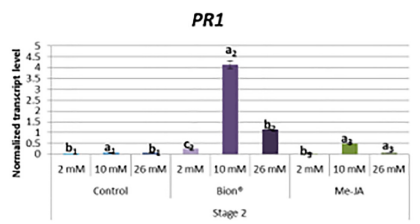

F

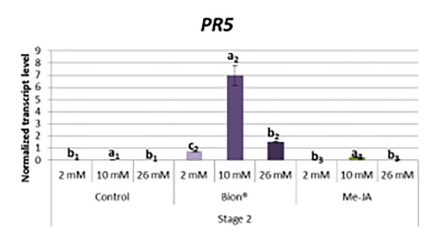

G

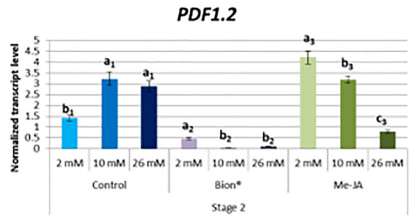

H

LOX2

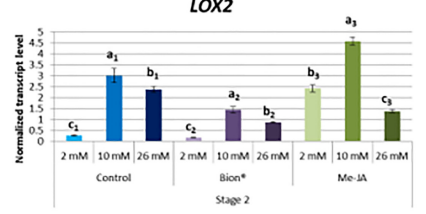

M

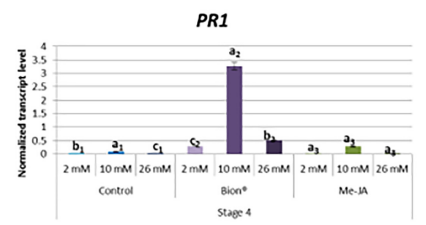

$\mathbf{N}$

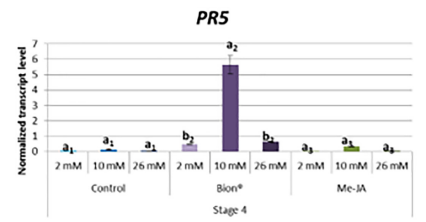

0

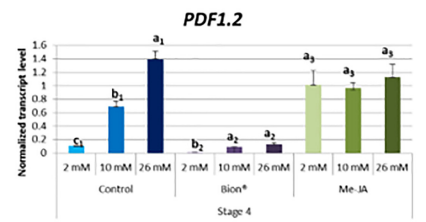

P

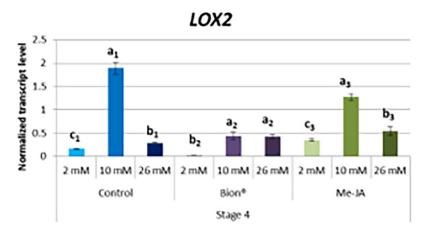

FIGURE 3 | Impact of nitrate nutrition on defense gene expression $48 \mathrm{~h}$ after plant defense stimulator treatment. Plants were cultivated until the indicated developmental stages (four stages) under the indicated nutritional conditions (2, 10, $26 \mathrm{mM}$ ). They were treated with Bion ${ }^{\circledast}$, MeJA or water as a control then harvested $48 \mathrm{~h}$ after treatment, 6 to 10 plants were harvested for each treatment in each experiment. Defense gene expression was monitored by q-RT-PCR. Data represent normalized transcript levels using Clathrin as a reference gene. (A-D) Indicate defense gene expression at stage 1; (E-H) Indicate defense gene expression at stage 2; (I-L) Indicate defense gene expression at stage 3; (M-P) Indicate defense gene expression at stage 4. Experiments were performed 3 to 4 times with similar results. Representative data are shown. Error bars represent standard error. Different letters represent statistically significant differences between plant defense stimulator treatments under the same nutritional condition $(p<0.05$ as calculated by $t$-test). 
A

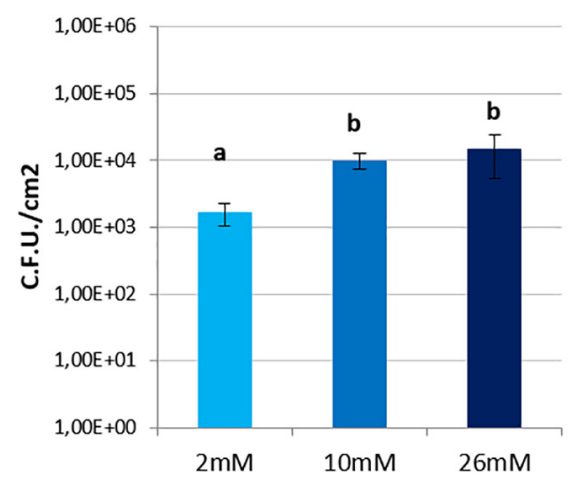

B

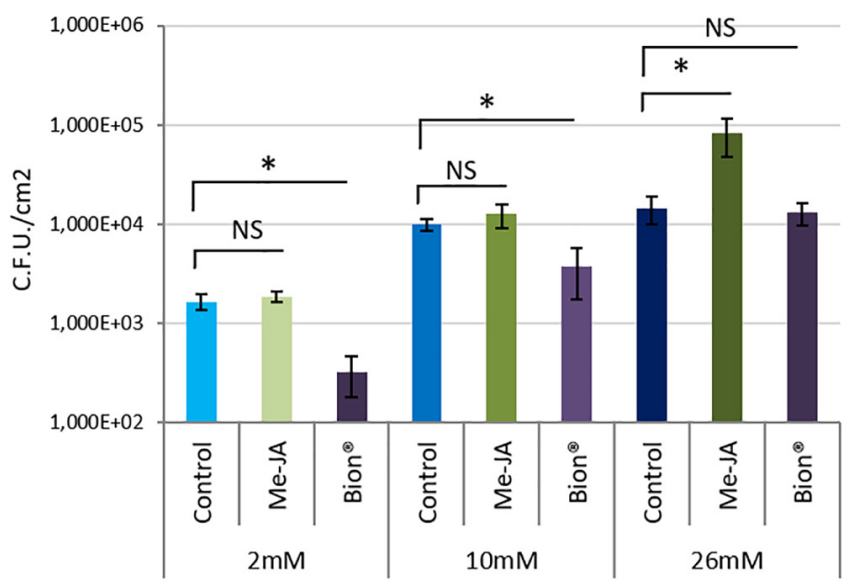

FIGURE 4 | Impact of nitrate fertilization on protection against the pathogenic bacterium Pseudomonas syringae pv. tomato after plant defense stimulator application. Plants were cultivated until developmental stage 2 (rosette) under the indicated nitrate nutritional conditions (2, 10,26 mM). They were treated with Bion ${ }^{\circledR}$, MeJA or water as a control, then inoculated with P. syringae pv. tomato $48 \mathrm{~h}$ after plant defense stimulator treatment. Bacterial populations were monitored. Error bar represent standard deviation. $N=20$ leaves. Different letters (A) or stars (B) represent statistically significant differences between control and plant defense stimulator treatments under the same nutritional conditions, NS represent "No Significant" differences ( $p<0.05$ as calculated by $t$-test). Experiments were performed three times with similar results. Representative data are shown.

nitrate compared to Col-0 WT plants (Figure 6C) which could explain the enhanced susceptibility of to D. dadantii in npr1-1 naive plants compared to Col-0 WT naïve plants (Figure 5A). The increased susceptibility of Col-0 WT plants to D. dadantii under $2 \mathrm{mM}$ nitrate following Bion ${ }^{\circledR}$ treatment (Figure 5B) is consistent with a down-regulation of PDF1.2 and LOX2 expression in Col-0 following Bion ${ }^{\circledR}$ treatment under $2 \mathrm{mM}$ nitrate (Figures 6C,D). Although this increased susceptibility is abolished in the npr1-1 mutant under these conditions, the down-regulation of PDF1.2 and LOX2 is still observed.

The protection of Col-0 WT plants agianst $D$. dadantii under $10 \mathrm{mM}$ nitrate following MeJA treatment (Figure 5B) is consistent with an up-regulation of LOX2 expression in Col-0 following MeJA treatment under $10 \mathrm{mM}$ nitrate (Figure 6C). Although this protection is abolished in the npr1-1 mutant, under these conditions, the up-regulation of LOX2 is still observed.

Taken together, these data indicate that NPR1 plays an important role in modulating Arabidopsis defenses depending on nitrate supply.

\section{DISCUSSION}

Most of the plant protection treatments directly target invading pathogens. In general, this kind of practices has proven to cause pathogen resistance toward pesticides, thus reducing their efficiency (Hahn, 2014). In addition, pesticide use has detrimental effects on animal health and environment. It is nowadays obvious that alternate and sustainable plant protection strategies are needed to avoid the detrimental effects of pesticide and reduce pathogen adaptation (Pretty, 2018). The use of plant defense stimulators is one of the proposed alternate crop protection strategies which is being investigated by scientists and farmers because they don't directly target the pathogen and they provide a wide protection range. However, plant defense stimulators efficiency is controversial. While they can protect plants from pathogen infections under controlled conditions, their efficiency in the field is often unstable (Bektas and Eulgem, 2015).

In this work, we investigated the possibility that plant responses to plant defense stimulators could be affected by the developmental stage and nitrogen nutrition. The objective was to determine whether by adjusting fertilization and targeting specific developmental stages, plant defense stimulators use could be optimized.

Plant intrinsic susceptibility to pathogens depends on plant developmental stage and nitrogen status. For instance, the bacterial fire blight causing pathogen Erwinia amylovora preferentially infects growing tissues and apple flowers (Malnoy et al., 2011). Conversely, senescence can be a factor which favors necrotrophic pathogen infection while it prevents biotrophic pathogen infections (Häffner et al., 2015). On the other hand, plant intrinsic susceptibility to pathogens can vary depending on the nitrogen fertilization. Complex interactions have been described concerning the connection between plant nitrogen status and tolerance to pathogens (Fagard et al., 2014; Mur et al., 2017; Sun et al., 2020). For instance, nitrate fertilization increases tomato tolerance to the fungal necrotroph Botrytis cinerea (Lecompte et al., 2010); while it increases the susceptibility of A. thaliana to this fungus (Fagard et al., 2014). Nitrogen fertilization has an impact on defense activation (Kruse et al., 2007; Kutyniok and Müller, 2013; Mur et al., 2017; Zarattini et al., 2017; Farjad et al., 2018) as well as on pathogen virulence factors (Van den Ackerveken et al., 1994; Snoeijers et al., 2000; Robert et al., 2004). Thus, the impact of nitrogen 
A
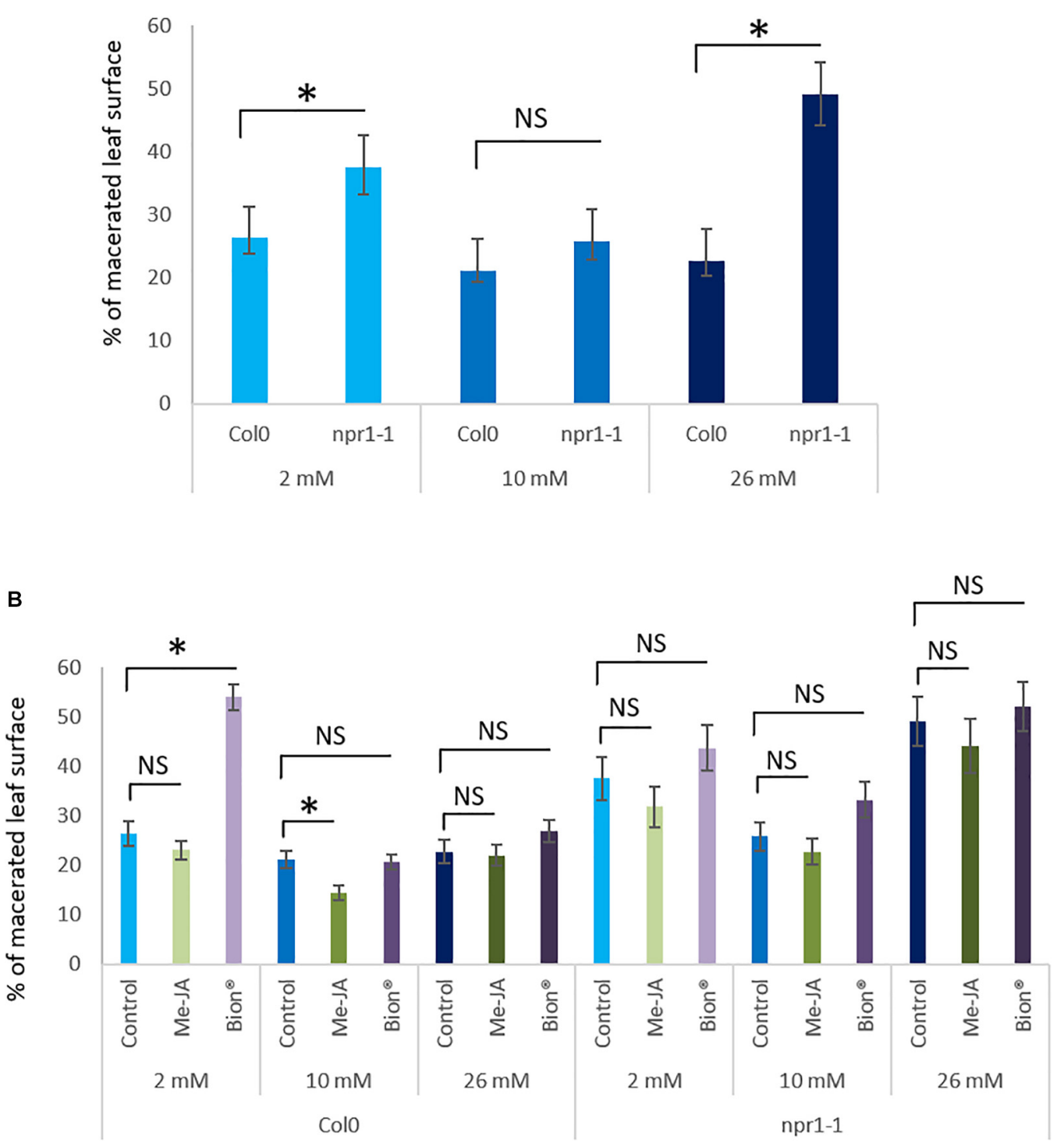

FIGURE 5 | Impact of nitrate fertilization on protection against the pathogenic bacterium $D$. dadantii after plant defense stimulator application on an $n p r 1$ mutant. Plants were cultivated until developmental stage 2 (rosette) under the indicated nitrate nutritional conditions (2, 10 , or 26 mM). They were treated with Bion ${ }^{\circledast}$, MeJA or water as a control, then inoculated with $D$. dadantii $48 \mathrm{~h}$ after plant defense stimulator treatment. Symptoms were scored $48 \mathrm{~h}$ after inoculation. Percentage of macerated leaf surface are represented. Error bars represent standard error. $N=20$ leaves. Stars represent statistically significant differences between $n p r 1-1$ mutant plants and wild type Col-O WT (A) and between control and MeJA and Bion ${ }^{\circledR}$, treatment (B) for each level of fertilization. NS represent "No Significant" differences $(p<0.05$ as calculated by $t$-test). Experiments were performed three times with similar results. Representative data are shown.

status on plant tolerance/susceptibility does not exclusively depend on nutritional availability to pathogen, but involves complex mechanisms.

The above-cited reports describe the impact of the developmental stage and nitrogen fertilization on plant intrinsic susceptibility to pathogens. However, very few data are available about the impact of the developmental stage and nitrogen fertilization on plant defense stimulator mediated defense activation. Our data show that the plant defense responses to two plant defense stimulators, which trigger two major defense signaling pathways are affected by both the developmental stage and nitrate nutrition in A. thaliana. Activation of SA pathway by Bion $^{\circledR}$ was dependent of both the nitrate supply and the developmental stage (Figures 2, 3), indicating that the fertilization and physiological stage parameters should be considered when using Bion ${ }^{\circledR}$ as an plant defense stimulator. Optimal nitrate nutritional conditions were the most favorable conditions for SA defense activation by Bion ${ }^{\circledR}$. Dietrich et al. (2004) showed that nitrogen limitation resulted in reduced defense 


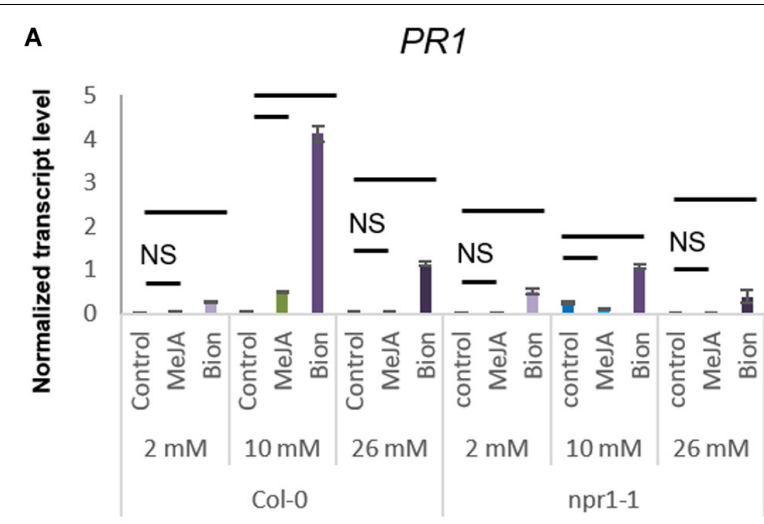

B

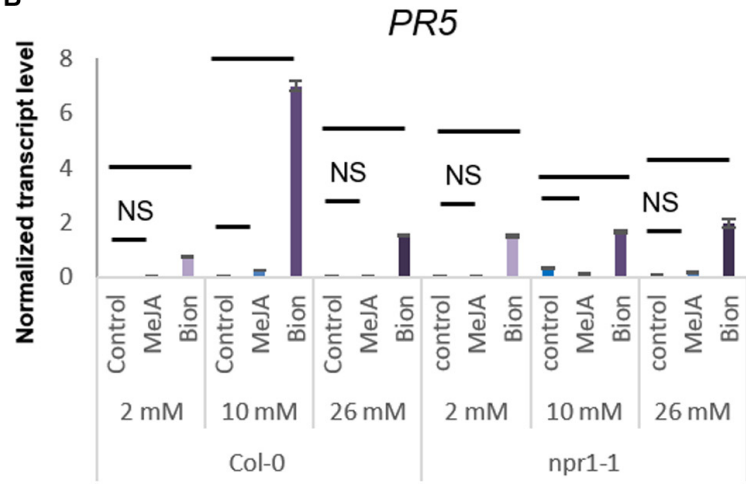

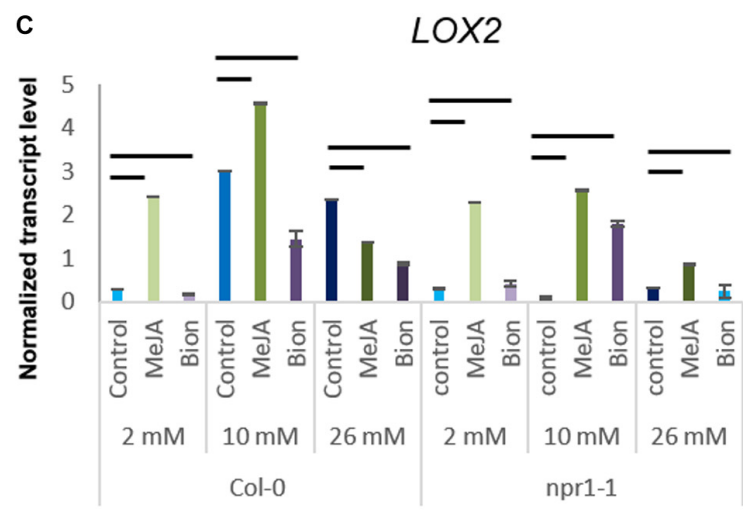

D

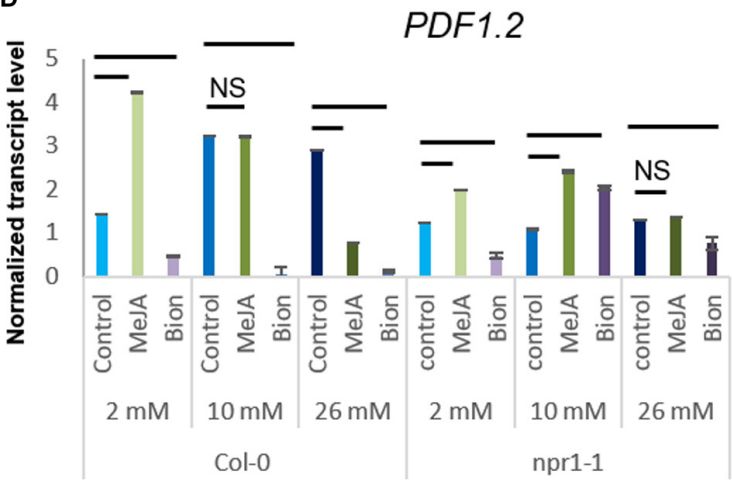

FIGURE 6 | Impact of nitrate nutrition on defense gene expression $48 \mathrm{~h}$ after elicitor treatment. Plants were cultivated until the developmental stage 2 under the indicated nutritional conditions (2, 10, $26 \mathrm{mM}$ nitrate). They were treated with Bion ${ }^{\circledR}$, MeJA or water as a control then harvested $48 \mathrm{~h}$ after treatment, 6 to 10 plants were harvested for each treatment in each experiment. Transcript levels of indictade genes, PR1 (A), PR5 (B), LOX2 (C), and PDF1.2 (D) was monitored by qRT-PCR. Data represent normalized transcript levels using Clathrin as a reference gene. Bars indicate comparisons between control and plant defense stimulator treatments under the same nutritional condition. When only a bar is visible, the difference is significant ( $p<0.05$ as calculated by $t$-test). NS: statistically Non-Significant differences between control and plant defense stimulator treatments under the same nutritional condition.

induction by Bion ${ }^{\circledR}$. In a transcriptomic approach to characterize the combined effect of pathogen and nitrogen deficiency, Farjad et al. (2018) showed that the upregulation of a set of defense related genes was higher under nitrogen limitation. Thus, depending on the biotic stress and the defense pathway considered, nitrogen deficiency can differentially affect immune responses. These studies did not investigate over-fertilization conditions.

Regulation of LOX2 and PDF1 transcript levels following MeJA treatment was strongly affected by nitrate supply and developmental stage (Figures 2, 3). Up-regulation was not observed in all cases and it was surprising to observe repression of these markers following MeJA treatment in some cases (Supplementary Figure 3). Both ET and JA play important roles in plant development (Huang et al., 2017; Dubois et al., 2018). Thus, the differential expression observed between stage 1 and 4 may be in part due to their accumulation level during these key developmental phases. Interestingly, an up-regulation of $P R 1$ and PR5 was observed following MeJA treatment although to a lower level than those observed following Bion ${ }^{\circledR}$ treatment. This dual activation of SA and JA pathways was also recently described in the context of plant resistance mediated by a specific resistance gene in Arabidopsis (Liu et al., 2016) and may be more common than usually assumed. The ET/JA pathway is recruited during induced systemic resistance (ISR) triggered by PGPR (Backer et al., 2018). It would be interesting to determine whether ISR is affected by plant developmental stage and nutrition.

The impact of nitrate supply on effective protection of MeJA and Bion ${ }^{\circledR}$ against two bacterial pathogens with different lifestyles was investigated. Bion ${ }^{\circledR}$ conferred protection against the hemibiotrohoic bacterium $P$. syringae pv. tomato under low and optimal nutrition but failed to protect under high nitrate. Conversely, MeJA treatment resulted in an increased plant susceptibility. Protection was conferred by MeJA against $D$. dadantii when plants were cultivated under optimal nitrate nutritional conditions with $10 \mathrm{mM}$ nitrate, while no protection was observed under low or over-fertilization conditions. This optimal protection is not perfectly correlated with transcriptional activation of PDF1.2 and $L O X 2$, indicating that these two defense markers do not fully explain the protection at optimal nitrate nutritional conditions. Interestingly, LOX2 expression, is up-regulated at stage 2 and under optimal nitrate nutrition 
which correspond to the conditions where MeJA protects plants against $D$. dadantii (Supplementary Figure 3) indicating that the JA pathway could be acting here via ISR. These data are consistent with the fact that JA is involved in A. thaliana defense against D. dadantii (Fagard et al., 2007; Reverchon and Nasser, 2013). While MeJA conferred protection against $D$. dadantii, Bion ${ }^{\circledR}$ treatment resulted in an increased susceptibility. This increased susceptibility could be explained by the repression of ET/JA defenses we observed following Bion ${ }^{\circledR}$ treatment which activates the SA pathway (Supplementary Figure 2). An antagonistic effect of the SA pathway over the ET/JA pathway was previously described (Koornneef and Pieterse, 2008; Leon-Reyes et al., 2010; Van der Does et al., 2013; Caarls et al., 2017; Li et al., 2019; Yang et al., 2019). Care must be taken when fighting diverse bioagressors in the field since plant defense stimulators can have opposite effects.

In order to determine the defense signaling contribution in the plant protection mediated by MeJA against $D$. dadantii, the npr1-1 mutant was used because this mutant was described as being affected in both the SA and the ET/JA defense responses (Pieterse and Van Loon, 2004; Withers and Dong, 2017; Barker, 2018; Backer et al., 2019). The enhanced susceptibility of the npr1-1 mutant could be surprising since this gene is commonly known to activate SA response which is effective against biotrophs. In the npr1-1 mutant, one could expect the increase in JA signaling leading to enhanced resistance to the necrotroph $D$. dadantii. However, several examples show that NPR1 overexpression leads to tolerance to necrotrophic pathogens (Wally et al., 2009; Ali et al., 2017). Our data show that MeJA mediated $A$. thaliana protection against $D$. dadantii requires NPR1. Similarly, Bion ${ }^{\circledR}$ mediated plant increased susceptibility to $D$. dadantii is abolished in the npr1-1 mutant. It is intriguing that both increased and decreased protection involve NPR1. To tackle this issue, the role of the SA and ET/JA defense signaling pathways in the defense modulation by NPR1 was investigated by monitoring the expression of defense gene markers of these pathways in the npr1-1 mutant under the different nutritional conditions and following plant defense stimulator treatments. Interestingly, LOX2 expression seems to both depend on NPR1 and nitrate supply. Indeed, LOX2 expression was strongly reduced in npr1-1 mutant plants under $26 \mathrm{mM}$ nitrate correlating with enhanced susceptibility to D. dadantii. Our data illustrate the complexity by which NPR1 is involved in the balance between the SA and the ET/JA signaling pathways that remains to be further investigated (Pieterse et al., 2011; Li et al., 2019).

The role of NPR1 in the nitrate dependent defense modulation by plant defense stimulators suggests a role of nitrate nutrition on defense signaling mechanisms. One

\section{REFERENCES}

Alhoraibi, H., Bigeard, J., Rayapuram, N., Colcombet, J., and Hirt, H. (2019). Plant immunity: the MTI-ETI model and beyond. Curr. Issues Mol. Biol. 30, 39-58. doi: 10.21775/cimb. 030.039 possible mechanism by which nitrate nutrition can interact with defense signaling is via NO accumulation which can be a byproduct of nitrate reductase. A. thaliana plants fertilized with nitrate accumulated higher levels of NO than ammonium fed plants suggesting an involvement of NO in the higher tolerance of nitrate fertilized plants to the pathogenic bacterium P. syringae (Gupta et al., 2012). The role of NO could be related to the activity of the NPR1 protein which is known to be S-nitrosylated (Tada et al., 2008; Withers and Dong, 2017).

These data support the idea that the impact of nitrate nutrition in plant immunity is complex and probably involves interactions between defense signaling pathways and metabolic pathways.

Our data could be useful to the design of performant agronomic practices by choosing and adapting the best fitted conditions for the use of plant defense stimulators taking into account the stage of development and the nitrogen status.

\section{DATA AVAILABILITY STATEMENT}

All datasets generated for this study are included in the article/Supplementary Material.

\section{AUTHOR CONTRIBUTIONS}

$\mathrm{AD}$ and M-ES-M conceived conceptually the work. CV and $\mathrm{AD}$ wrote the manuscript. $\mathrm{CV}, \mathrm{ACRD}$, and $\mathrm{MR}$ performed the experiences. AD, M-ES-M, LR, and FG supervised the project.

\section{ACKNOWLEDGMENTS}

The authors want to thank the Staphyt Company and the National Agency of Research and Technology (ANRT) which funded the Ph.D. fellowship of CV supported by Paris Saclay University and the Jean-Pierre Bourgin Institut (IJPB) for the provision of scientific equipment and the reception within the institute that led to this work. The IJPB benefits from the support of Saclay Plant Sciences-SPS (ANR-17-EUR-0007). This work has benefited from the support of IJPB's Plant Observatory technological platforms.

\section{SUPPLEMENTARY MATERIAL}

The Supplementary Material for this article can be found online at: https://www.frontiersin.org/articles/10.3389/fpls.2020.00583/ full\#supplementary-material

Ali, S., Mir, Z. A., Tyagi, A., Mehari, H., Meena, R. P., Bhat, J. A., et al. (2017). Overexpression of NPR1 in Brassica juncea confers broad spectrum resistance to fungal pathogens. Front. Plant. Sci. 8:1693. doi: 10.3389/fpls.2017. 01693

Aznar, A., Chen, N. W. G., Rigault, M., Riache, N., Joseph, D., Desmaële, D., et al. (2014). Scavenging Iron: a novel mechanism of plant immunity activation by 
microbial siderophores. Plant Physiol. 164, 2167-2183. doi: 10.1104/pp.113.23 3585

Aznar, A., Chen, N. W. G., Thomine, S., and Dellagi, A. (2015). Immunity to plant pathogens and iron homeostasis. Plant Sci. 240, 90-97. doi: 10.1016/j.plantsci. 2015.08.022

Backer, R., Naidoo, S., and van den Berg, N. (2019). The NONEXPRESSOR OF PATHOGENESIS-RELATEDGENES 1 (NPR1) and related family: mechanistic insights in plant disease resistance. Front Plant Sci. 10:102. doi: 10.3389/fpls. 2019.00102

Backer, R., Rokem, J. S., Ilangumaran, G., Lamont, J., Praslickova, D., Ricci, E., et al. (2018). Plant growth-promoting rhizobacteria: context, mechanisms of action, and roadmap to commercialization of biostiulants for sustainable agriculture. Front. Plant Sci. 9:1473. doi: 10.3389/fpls.2018.01473

Barker, C. (2018). Systemic acquired resistance. Annu. Plant Rev. 209-229. doi: 10.1002/9781119312994.apr0032

Bektas, Y., and Eulgem, T. (2015). Synthetic plant defense plant defense stimulators. Front. Plant Sci. 5:804. doi: 10.3389/fpls.2014.00804

Boyes, D. C., Zayed, A. M., Ascenzi, R., McCaskill, A. J., Hoffman, N. E., Davis, K. R., et al. (2001). Growth Stage-based phenotypic analysis of Arabidopsis: a model for high throughput functional genomics in plants. Plant Cell 13, 1499-1510. doi: $10.2307 / 3871382$

Bürger, M., and Chory, J. (2019). Stressed out about hormones: how plants orchestrate immunity. Cell Host Microbe 26, 163-172. doi: 10.1016/j.chom. 2019.07.006

Caarls, L., Der Does, D., Van Hickman, R., Jansen, W., Van Verk, M. C., Proietti, S., et al. (2017). Assessing the role of ETHYLENE RESPONSE FACTOR transcriptional repressors in salicylic acid-mediated suppression of jasmonic acid-responsive genes. Plant Cell Physiol. 58, 266-278. doi: 10.1093/pcp/pcw187

Caarls, L., Pieterse, C. M., and Van Wees, S. C. (2015). How salicylic acid takes transcriptional control over jasmonic acid signaling. Front. Plant Sci. 6:170. doi: $10.3389 /$ fpls.2015.00170

Cao, H., Glazebrook, J., Clarke, J. D., Volko, S., and Dong, X. (1997). The Arabidopsis NPR1 gene that controls systemic acquired resistance encodes a novel protein containing ankyrin repeats. Cell 88, 57-63. doi: 10.1016/S00928674(00)81858-9

Cao, H., Li, X., and Dong, X. (1998). Generation of broad-spectrum disease resistance by overexpression of an essential regulatory gene in systemic acquired resistance. Proc. Natl. Acad. Sci. U.S.A. 11, 6531-6536. doi: 10.1073/pnas.95.11. 6531

Carella, P., Wilson, D. C., and Cameron, R. K. (2015). Some things get better with age: differences in salicylic acid accumulation and defense signaling in young and mature Arabidopsis. Front. Plant Sci. 5:775. doi: 10.3389/fpls.2014.00775

Chen, Y. L., Lee, C. Y., Cheng, K. T., Chang, W. H., Huang, R. N., Nam, H. G., et al. (2014). Quantitative peptidomics study reveals that a wound-induced peptide from PR-1 regulates immune signalling in tomato. Plant Cell 26, 4135-4148. doi: $10.1105 /$ tpc.114.131185

Chern, M. S., Fitzgerald, H. A., Yadav, R. C., Canlas, P. E., Dong, X., and Ronald, P. C. (2001). Evidence for a disease-resistance pathway in rice similar to the NPR1-mediated signaling pathway in Arabidopsis. Plant J. 27, 101-113. doi: 10.1046/j.1365-313X.2001.01070.x

De Wit, M., Gommers, C. M. M., Voesenek, L. A. C. J., Pierik, R., Spoel, S. H., Sanchez-Perez, G. F., et al. (2013). Perception of low red: far-red ratio compromises both salicylic acid- and jasmonic acid-dependent pathogen defences in Arabidopsis. Plant J. 75, 90-103. doi: 10.1111/tpj.12203

Després, C., DeLong, C., Glaze, S., Liu, E., and Fobert, P. R. (2000). The Arabidopsis NPR1/NIM1 protein enhances the DNA binding activity of a subgroup of the TGA family of bZIP transcription factors. Plant Cell 12, 279L-290. doi: 10.1105/tpc.12.2.279

Dietrich, R., Ploß, K., and Heil, M. (2004). Constitutive and induced resistance to pathogens in Arabidopsis thaliana depends on nitrogen supply. Plant Cell Environ. 27, 896-906. doi: 10.1111/j.1365-3040.2004.01195.x

Ding, Y., Sun, T., Ao, K., Peng, Y., Zhang, Y., Li, X., et al. (2018). Opposite roles of salicylic acid receptors NPR1 and NPR3/NPR4 in transcriptional regulation of plant immunity. Cell 6, 1454-1467.e15. doi: 10.1016/j.cell.2018. 03.044

Dubois, M., Van den Broeck, L., and Inzé, D. (2018). The pivotal role of ethylene in plant growth. Trends Plant Sci. 23, 311-323. doi: 10.1016/j.tplants.2018. 01.003
Durrant, W. E., and Dong, X. (2004). Systemic acquired resistance. Annu. Rev. Phytopathol. 1, 179-184. doi: 10.1146/annurev.phyto.42.040803.140421

Eyles, A., Chorbadjian, R., Wallis, C., Hansen, R., Cipollini, D., Herms, D., et al. (2007). Cross-induction of systemic induced resistance between an insect and a fungal pathogen in Austrian pine over a fertility gradient. Oecologia 153, 365-374. doi: 10.1007/s00442-007-0741-z

Fagard, M., Dellagi, A., Roux, C., Périno, C., Rigault, M., Boucher, V., et al. (2007). Arabidopsis thaliana expresses multiple lines of defense to counterattack Erwinia chrysanthemi. Mol. Plant-Microbe Interact. 20, 794-805. doi: 10.1094/ MPMI-20-7-0794

Fagard, M., Launay, A., Clément, G., Courtial, J., Dellagi, A., Farjad, M., et al. (2014). Nitrogen metabolism meets phytopathology. J. Exp. Bot. 65, 5643-5656. doi: $10.1093 /$ jxb/eru323

Farjad, M., Rigault, M., Pateyron, S., Martin-Magniette, M.-L., Krapp, A., Meyer, C., et al. (2018). Nitrogen limitation alters the response of specific genes to biotic stress. Int. J. Mol. Sci. 19:3364. doi: 10.3390/ijms19113364

Gamir, J., Darwiche, R., Van't Hof, P., Choudhary, V., Stumpe, M., Schneiter, R., et al. (2017). The sterol-binding activity of PATHOGENESIS-RELATED PROTEIN 1 reveals the mode of action of an antimicrobial protein. Plant J. 89, 502-509. doi: 10.1111/tpj.13398

Glauser, G., Dubugnon, L., Mousavi, S. A., Rudaz, S., Wolfender, J. L., and Farmer, E. E. (2009). Velocity estimates for signal propagation leading to systemic jasmonic acid accumulation in wounded Arabidopsis. J. Biol. Chem. 284, 3450634513. doi: 10.1074/jbc.M109.061432

Glazebrook, J. (2005). Contrasting mechanisms of defense against biotrophic and necrotrophic pathogens. Annu. Rev. Phytopathol. 43, 205-227. doi: 10.1146/ annurev.phyto.43.040204.135923

Gupta, K. J., Brotman, Y., Segu, S., Zeier, T., Zeier, J., Persijn, S. T., et al. (2012). The form of nitrogen nutrition affects resistance against Pseudomonas syringae pv. phaseolicola in tobacco. J. Exp. Bot. 64, 553-568. doi: 10.1093/jxb/ers348

Häffner, E., Konietzki, S., and Diederichsen, E. (2015). Keeping control: the role of senescence and development in plant pathogenesis and defense. Plants 4, 449-488. doi: 10.3390/plants4030449

Hahn, M. (2014). The rising threat of fungicide resistance in plant pathogenic fungi: botrytis as a case study. J. Chem. Biol. 7, 133-141. doi: 10.1007/s12154014-0113-1

Heil, M., and Bostock, R. M. (2002). Induced systemic resistance (ISR) against pathogens in the context of induced plant defences. Ann. Bot. 89, 503-512. doi: $10.1093 / \mathrm{aob} / \mathrm{mcf076}$

Hirel, B., Le Gouis, J., Ney, B., and Gallais, A. (2007). The challenge of improving nitrogen use efficiency in crop plants: towards a more central role for genetic variability and quantitative genetics within integrated approaches. J. Exp. Bot. 58, 2369-2387. doi: 10.1093/jxb/erm097

Huang, H., Liu, B., Liu, L., and Song, S. (2017). Jasmonate action in plant growth and development. J. Exp. Bot. 68, 1349-1359. doi: 10.1093/jxb/erw495

Janda, M., Navrátil, O., Haisel, D., Jindřichová, B., Fousek, J., Burketová, L., et al. (2015). Growth and stress response in Arabidopsis thaliana, Nicotiana benthamiana, Glycine max, Solanum tuberosum and Brassica napus cultivated under polychromatic LEDs. Plant Methods 11:31. doi: 10.1186/s13007-0150076-4

Jones, J. D. G., and Dangl, J. L. (2006). The plant immune system. Nature 444, 323-329. doi: 10.1038/nature05286

Kazan, K., and Manners, J. M. (2011). The interplay between light and jasmonate signalling during defence and development. J. Exp. Bot. 62, 4087-4100. doi: $10.1093 /$ jxb/err142

King, E. O., Ward, M. K., and Raney, D. E. (1954). Two simple media for the demonstration of pyocyanin and fluorescin. J. Lab. Clin. Med. 44, 301-307.

Kinkema, M., Fan, W., and Dong, X. (2000). Nuclear localization of NPR1 is required for activation of \&lt;em\&gt;PR\&lt;/em\&gt; gene expression. Plant Cell 12, 2339L-2350L. doi: 10.1105/tpc.12.12.2339

Klessig, D. F., Choi, H. W., and Dempsey, D. A. (2018). Systemic acquired resistance and salicylic acid: past, present, and future. Mol. Plant-Microbe Interact. 31, 871-888. doi: 10.1094/mpmi-03-18-0067-cr

Koornneef, A., and Pieterse, C. M. J. (2008). Cross talk in defense signaling. Plant Physiol. 146, 839-844. doi: 10.1104/pp.107.112029

Krapp, A., David, L. C., Chardin, C., Girin, T., Marmagne, A., Leprince, A. S., et al. (2014). Nitrate transport and signalling in Arabidopsis. J. Exp. Bot. 65, 789-798. doi: $10.1093 /$ jxb/eru001 
Kruse, C., Jost, R., Lipschis, M., Kopp, B., Hartmann, M., and Hell, R. (2007). Sulfur-enhanced defence: effects of sulfur metabolism, nitrogen supply, and pathogen lifestyle. Plant Biol. 9, 608-619. doi: 10.1055/s-2007-965432

Kuai, X., MacLeod, B. J., and Després, C. (2015). Integrating data on the Arabidopsis NPR1/NPR3/NPR4 salicylic acid receptors; a differentiating argument. Front. Plant Sci. 6:235. doi: 10.3389/fpls.2015.00235

Kutyniok, M., and Müller, C. (2013). Plant-mediated interactions between shootfeeding aphids and root-feeding nematodes depend on nitrate fertilization. Oecologia 173, 1367-1377. doi: 10.1007/s00442-013-2712-x

Lecompte, F., Abro, M. A., and Nicot, P. C. (2010). Contrasted responses of Botrytis cinerea isolates developing on tomato plants grown under different nitrogen nutrition regimes. Plant Pathol. 59, 891-899. doi: 10.1111/j.1365-3059.2010. 02320.x

Lemaître, T., Gaufichon, L., Boutet-Mercey, S., Christ, A., and MasclauxDaubresse, C. (2008). Enzymatic and metabolic diagnostic of nitrogen deficiency in Arabidopsis thaliana Wassileskija accession. Plant Cell Physiol. 49, 1056-1065. doi: 10.1093/pcp/pcn081

Leon-Reyes, A., Van der Does, D., De Lange, E. S., Delker, C., Wasternack, C., Van Wees, S. C. M., et al. (2010). Salicylate-mediated suppression of jasmonateresponsive gene expression in Arabidopsis is targeted downstream of the jasmonate biosynthesis pathway. Planta 232, 1423-1432. doi: 10.1007/s00425010-1265-z

Li, J., Brader, G., and Palva, E. T. (2004). The WRKY70 transcription factor: a node of convergence for jasmonate-mediated and salicylate-mediated signals in plant defense. Plant Cell 16, 319-331. doi: 10.1105/tpc.016980

Li, N., Han, X., Feng, D., Yuan, D., and Huang, L. J. (2019). Signaling crosstalk between salicylic acid and ethylene/jasmonate in plant defense: do we understand what they are whispering? Int. J. Mol. Sci. 20:E671. doi: 10.3390/ ijms20030671

Liu, L., Sonbol, F. M., Huot, B., Gu, Y., Withers, J., Mwimba, M., et al. (2016). Salicylic acid receptors activate jasmonic acid signalling through a noncanonical pathway to promote effector-triggered immunity. Nat. Commun. 7:13099. doi: 10.1038/ncomms13099

Loudet, O., Chaillou, S., Merigout, P., Talbotec, J., and Daniel-Vedele, F. (2003). Quantitative trait loci analysis of nitrogen use efficiency in Arabidopsis. Plant Physiol. 1, 345-358. Erratum in: Plant Physiol. 2003 Mar;131(3):1508. doi: 10. 1104/pp.102.010785

Malnoy, M., Martens, S., Norelli, J. L., Barny, M.-A., Sundin, G. W., Smits, T. H. M., et al. (2011). Fire blight: applied genomic insights of the pathogen and host. Annu. Rev. Phytopathol. 50, 475-494. doi: 10.1146/annurev-phyto-081211172931

Manners, J. M., Penninckx, I. A. M. A., Vermaere, K., Kazan, K., Brown, R. L., Morgan, A., et al. (1998). The promoter of the plant defensin gene PDF1.2 from Arabidopsis is systemically activated by fungal pathogens and responds to methyl jasmonate but not to salicylic acid. Plant Mol. Biol. 38, 1071-1080. doi: 10.1023/A:1006070413843

Manohar, M., Tian, M., Moreau, M., Park, S. W., Choi, H. W., Fei, Z., et al. (2015). Identification of multiple salicylic acid-binding proteins using two high throughput screens. Front. Plant Sci. 5:777. doi: 10.3389/fpls.2014.00777

Mao, P., Duan, M., Wei, C., and Li, Y. (2007). WRKY62 transcription factor acts downstream of cytosolic NPR1 and negatively regulates jasmonate-responsive gene expression. Plant Cell Physiol. 48, 833-842. doi: 10.1093/pcp/pcm058

Masclaux-Daubresse, C., Daniel-Vedele, F., Dechorgnat, J., Chardon, F., Gaufichon, L., and Suzuki, A. (2010). Nitrogen uptake, assimilation and remobilization in plants: challenges for sustainable and productive agriculture. Ann. Bot. 105, 1141-1157. doi: 10.1093/aob/mcq028

McCann, H. C., Nahal, H., Thakur, S., and Guttman, D. S. (2012). Identification of innate immunity elicitors using molecular signatures of natural selection. Proc. Natl. Acad. Sci. USA. 109, 4215-4220. doi: 10.1073/pnas.1113893109

Mengiste, T. (2012). Plant immunity to necrotrophs. Annu. Rev. Phytopathol. 50, 267-294. doi: 10.1146/annurev-phyto-081211-172955

Miller, R. N., Costa Alves, G. S., and Van Sluys, M. A. (2017). Plant immunity: unravelling the complexity of plant responses to biotic stresses. Ann. Bot. 119, 681-687. doi: 10.1093/aob/mcw284

Mintoff, S. J. L., Rookes, J. E., and Cahill, D. M. (2015). Sub-lethal UV-C radiation induces callose, hydrogen peroxide and defence-related gene expression in Arabidopsis thaliana. Plant Biol. 17, 703-711. doi: 10.1111/plb.12286
Miranda, K. M., Espey, M. G., and Wink, D. A. (2001). A rapid, simple spectrophotometric method for simultaneous detection of nitrate and nitrite. Nitric Oxide - Biol. Chem. 5, 62-71. doi: 10.1006/niox.2000.0319

Mou, Z., Fan, W., and Dong, X. (2003). Inducers of plant systemic acquired resistance regulate NPR1 function through redox changes. Cell 113, 935-944. doi: 10.1016/S0092-8674(03)00429-X

Mur, L. A. J., Kenton, P., Atzorn, R., Miersch, O., and Wasternack, C. (2006). The outcomes of concentration-specific interactions between salicylate and jasmonate signaling include synergy, antagonism, and oxidative stress leading to cell death. Plant Physiol. 140, 249-262. doi: 10.1104/pp.105.072348

Mur, L. A. J., Simpson, C., Kumari, A., Gupta, A. K., and Gupta, K. J. (2017). Moving nitrogen to the centre of plant defence against pathogens. Ann. Bot. 119, 703-709. doi: 10.1093/aob/mcw179

Ndamukong, I., Abdallat, A. A., Thurow, C., Fode, B., Zander, M., Weigel, R., et al. (2007). A-inducible Arabidopsis glutaredoxin interacts with TGA factors and suppresses JA-responsive PDF1.2 transcription. Plant J. 50, 128-139. doi: 10.1111/j.1365-313X.2007.03039.x

Nejat, N., and Mantri, N. (2017). Plant immune system: crosstalk between responses to biotic and abiotic stresses the missing link in understanding plant defence. Curr. Issues Mol. Biol. 23, 1-16. doi: 10.21775/cimb.023.001

Nie, P., Li, X., Wang, S., Guo, J., Zhao, H., and Niu, D. (2017). Induced systemic resistance against Botrytis cinerea by Bacillus cereus AR156 through a JA/ET- and NPR1-dependent signaling pathway and activates PAMP-triggered immunity in Arabidopsis. Front. Plant Sci. 8, 238. doi: 10.3389/fpls.2017.00238

Pato, J., and Obeso, J. R. (2013). Effects of clipping and N fertilization on insect herbivory and infestation by pathogenic fungi on bilberry. Basic Appl. Ecol. 14, 347-356. doi: 10.1016/j.baae.2013.02.005

Piasecka, A., Jedrzejczak-Rey, N., and Bednarek, P. (2015). Secondary metabolites in plant innate immunity: conserved function of divergent chemicals. New Phytol. 3, 948-964. doi: 10.1111/nph.13325

Pieterse, C. M. J., Van der Does, D., Zamioudis, C., Leon-Reyes, A., and Van Wees, S. C. M. (2011). Hormonal modulation of plant immunity. Annu. Rev. Cell Dev. Biol. 28, 489-521. doi: 10.1146/annurev-cellbio-092910-154055

Pieterse, C. M. J., and Van Loon, L. C. (1999). Salicylic acid-independent plant defence pathways. Trends Plant Sci. 4, 52-58. doi: 10.1016/S1360-1385(98) 01364-8

Pieterse, C. M. J., and Van Loon, L. C. (2004). NPR1: the spider in the web of induced resistance signaling pathways. Curr. Opin. Plant Biol. 7, 456-464. doi: 10.1016/j.pbi.2004.05.006

Pieterse, C. M. J., Zamioudis, C., Berendsen, R. L., Weller, D. M., Van Wees, S. C. M., and Bakker, P. A. H. M. (2014). Induced systemic resistance by beneficial microbes. Annu. Rev. Phytopathol. 52, 347-375. doi: 10.1146/ annurev-phyto-082712-102340

Poschenrieder, C., Tolrà, R., and Barceló, J. (2006). Can metals defend plants against biotic stress? Trends Plant Sci. 11, 288-295. doi: 10.1016/j.tplants.2006. 04.007

Pretty, J. (2018). Intensification for redesigned and sustainable agricultural systems. Science (80-) 362:eaav0294. doi: 10.1126/science.aav0294

Ramamoorthy, V., Viswanathan, R., Raguchander, T., Prakasam, V., and Samiyappan, R. (2001). Induction of systemic resistance by plant growth promoting rhizobacteria in crop plants against pests and diseases. Crop Prot. 20, 1-11. doi: 10.1016/S0261-2194(00)00056-9

Reverchon, S., and Nasser, W. (2013). Dickeya ecology, environment sensing and regulation of virulence programme. Environ. Microbiol. Rep. 5, 622-636. doi: 10.1111/1758-2229.12073

Rigault, M., Buellet, A., Masclaux-Daubresse, C., Fagard, M., Chardon, F., and Dellagi, A. (2017). Quantitative methods to assess differential susceptibility of Arabidopsis thaliana natural accessions to Dickeya dadantii. Front. Plant Sci. 8:394. doi: 10.3389/fpls.2017.00394

Robert, C., Bancal, M.-O., and Lannou, C. (2004). Wheat leaf rust uredospore production on adult plants: influence of leaf nitrogen content and Septoria tritici blotch. Phytopathology 94, 712-721. doi: 10.1094/PHYTO.2004.94.7.712

Rosen, H. (1957). A modified ninhydrin colorimetric analysis for amino acids. Arch. Biochem. Biophys. 67, 10-15. doi: 10.1016/0003-9861(57)90241-2

Ruan, J., Zhou, Y., Zhou, M., Yan, J., Khurshid, M., Weng, W., et al. (2019). Jasmonic acid signaling pathway in plants. Int. J. Mol. Sci. 20:2479. doi: 10.3390/ ijms20102479 
Rufián, J. S., Rueda-Blanco, J., Beuzón, C. R., and Ruiz-Albert, J. (2019). Protocol: an improved method to quantify activation of systemic acquired resistance (SAR). Plant Methods. 15:16. doi: 10.1186/s13007-0190400-5

Shaner, G., and Finney, R. E. (1977). The effect of nitrogen fertilization on the expression of slow-mildewing resistance in knox wheat. Phytopathology 67, 1051-1056. doi: 10.1094/Phyto-67-1051

Shine, M. B., Xiao, X., Kachroo, P., and Kachroo, A. (2019). Signaling mechanisms underlying systemic acquired resistance to microbial pathogens. Plant Sci. 279, 81-86. doi: 10.1016/j.plantsci.2018.01.001

Snoeijers, S. S., Pérez-García, A., Joosten, M. H. A. J., and De Wit, P. J. G. M. (2000). The effect of nitrogen on disease development and gene expression in bacterial and fungal plant pathogens. Eur. J. Plant Pathol. 106, 493-506. doi: 10.1023/A:1008720704105

Spoel, S. H., Johnson, J. S., and Dong, X. (2007). Regulation of tradeoffs between plant defenses against pathogens with different lifestyles. Proc. Natl. Acad. Sci. U.S.A. 104, 18842-18847. doi: 10.1073/pnas.0708139104

Spoel, S. H., Koornneef, A., Claessens, S. M. C., Korzelius, J. P., Van Pelt, J. A., Mueller, M. J., et al. (2003). NPR1 modulates cross-talk between salicylate- and jasmonate-dependent defense pathways through a novel function in the cytosol. Plant Cell 15, 760-770. doi: 10.1105/tpc.009159

Steimetz, E., Trouvelot, S., Gindro, K., Bordier, A., Poinssot, B., Adrian, M., et al. (2012). Influence of leaf age on induced resistance in grapevine against Plasmopara viticola. Physiol. Mol. Plant Pathol. 79, 89-96. doi: 10.1016/j.pmpp. 2012.05.004

Sun, Y., Wang, M., Mur, L. A. J., Shen, Q., Guo, S., and Unravelling the Roles of Nitrogen. (2020). Nutrition in plant disease defences. Int. J. Mol. Sci. 21:E572. doi: 10.3390/ijms21020572

Tada, Y., Spoel, S. H., Pajerowska-Mukhtar, K., Mou, Z., Song, J., Wang, C., et al. (2008). Plant immunity requires conformational charges of NPR1 via S-nitrosylation and thioredoxins. Science (80-) 321, 952L-956. doi: 10.1126/ science. 1156970

Thaler, J. S., Humphrey, P. T., and Whiteman, N. K. (2012). Evolution of jasmonate and salicylate signal crosstalk. Trends Plant Sci. 17, 260-270. doi: 10.1016/j. tplants.2012.02.010

Thomma, B. P. H. J., Eggermont, K., Penninckx, I. A. M. A., MauchMani, B., Vogelsang, R., Cammue, B. P. A., et al. (1998). Separate jasmonate-dependent and salicylate-dependent defense-response pathways in Arabidopsis are essential for resistance to distinct microbial pathogens. Proc. Natl. Acad. Sci. U.S.A. 95, 15107-15111. doi: 10.1073/pnas.95.25. 15107

Uknes, S., Mauch-Mani, B., Moyer, M., Potter, S., Williams, S., Dincher, S., et al. (1992). Acquired resistance in Arabidopsis. Plant Cell. 6, 645-656.

Van den Ackerveken, G. F. J. M., Dunn, R. M., Cozijnsen, A. J., Vossen, J. P. M. J., Van den Broek, H. W. J., and De Wit, P. J. G. M. (1994). Nitrogen limitation induces expression of the avirulence gene avr9 in the tomato pathogen Cladosporium fulvum. MGG Mol. Gen. Genet. 243, 277-285. doi: 10.1007/ BF00301063

Van der Does, D., Leon-Reyes, A., Koornneef, A., Van Verk, M. C., Rodenburg, N., Pauwels, L., et al. (2013). Salicylic acid suppresses jasmonic acid signaling downstream of SCF COI1 -JAZ by targeting GCC promoter motifs via transcription factor ORA59. Plant Cell 25, 744-761. doi: 10.1105/tpc.112. 108548

van Loon, L. C., Rep, M., and Pieterse, C. M. J. (2006). Significance of inducible defense-related proteins in infected plants. Annu. Rev. Phytopathol. 44, 135 162. doi: 10.1146/annurev.phyto.44.070505.143425

Van Wees, S. C. M., Luijendijk, M., Smoorenburg, I., Van Loon, L. C., and Pieterse, C. M. J. (1999). Rhizobacteria-mediated induced systemic resistance (ISR Arabidopsis is not associated with a direct effect on expression of known defense-related genes but stimulates the expression of the jasmonate-inducible gene Atvsp upon challenge. Plant Mol. Biol. 41, 537-549. doi: 10.1023/A: 1006319216982

Veresoglou, S. D., Barto, E. K., Menexes, G., and Rillig, M. C. (2013). Fertilization affects severity of disease caused by fungal plant pathogens. Plant Pathol. 62, 961-969. doi: 10.1111/ppa.12014
Vos, I. A., Moritz, L., Pieterse, C. M. J., and Van Wees, S. C. M. (2015). Impact of hormonal crosstalk on plant resistance and fitness under multi-attacker conditions. Front. Plant Sci. 6:639. doi: 10.3389/fpls.2015.00639

Wally, O., Jayaraj, J., and Punja, Z. K. (2009). Broad-spectrum disease resistance to necrotrophic and biotrophic pathogens in transgenic carrots (Daucus carota L.) expressing an Arabidopsis NPR1 gene. Planta 231, 131-141. doi: 10.1007/ s00425-009-1031-2

Walters, D., Walsh, D., Newton, A., and Lyon, G. (2007). Induced resistance for plant disease control: maximizing the efficacy of resistance plant defense stimulators. Phytopathology 95, 1368-1373. doi: 10.1094/phyto-951368

Wang, W., Feng, B., Zhou, J. M., and Tang, D. (2020). Plant immune signaling: advancing on two frontiers. J. Integr. Plant Biol. 62, 2-24. doi: 10.1111/jipb. 12898

Wang, Y.-Y., Cheng, Y.-H., Chen, K.-E., and Tsay, Y.-F. (2018). Nitrate transport, signaling, and use efficiency. Annu. Rev. Plant Biol. 69, 85-122. doi: 10.1146/ annurev-arplant-042817-040056

Wirthmueller, L., Maqbool, A., and Banfield, M. J. (2013). On the front line: structural insights into plant-pathogen interactions. Nat. Rev. Microbiol. 11:761. doi: $10.1038 /$ nrmicro3118

Withers, J., and Dong, X. (2016). Posttranslational modifications of NPR1: a single protein playing multiple roles in plant immunity and physiology. PLoS Pathog. 12:e1005707. doi: 10.1371/journal.ppat.1005707

Withers, J., and Dong, X. (2017). Post-translational regulation of plant immunity. Curr. Opin. Plant Biol. 38, 124-132. doi: 10.1016/j.pbi.2017.05.004

Wu, Y., Zhang, D., Chu, J. Y., Boyle, P., Wang, Y., Brindle, I. D., et al. (2012). The Arabidopsis NPR1 protein is a receptor for the plant defense hormone salicylic acid. Cell Rep. 6, 639-647. doi: 10.1016/j.celrep.2012.05.008

Xin, X. F., and He, S.-Y. (2013). Pseudomonas syringae pv. tomato DC3000: a model pathogen for probing disease susceptibility and hormone signaling in plants. Annu. Rev. Phytopathol. 51, 473-498. doi: 10.1146/annurev-phyto-082712102321

Yang, J., Duan, G., Li, C., Liu, L., Han, G., Zhang, Y., et al. (2019). The crosstalks between jasmonic acid and other plant hormone signaling highlight the involvement of jasmonic acid as a core component in plant response to biotic and abiotic stresses. Front. Plant Sci. 10:1349. doi: 10.3389/fpls.2019.01349

Yuan, Y., Zhong, S., Li, Q., Zhu, Z., Lou, Y., Wang, L., et al. (2007). Functional analysis of rice NPR1-like genes reveals that OsNPR1/NH1 is the rice orthologue conferring disease resistance with enhanced herbivore susceptibility. Plant Biotechnol. J. 5, 313-324. doi: 10.1111/j.1467-7652.2007. 00243.x

Zarattini, M., Launay, A., Farjad, M., Wénès, E., Taconnat, L., Boutet, S., et al. (2017). The bile acid deoxycholate elicits defences in Arabidopsis and reduces bacterial infection. Mol. Plant Pathol. 18, 540-554. doi: 10.1111/mpp.12416

Zhang, Y., and Li, X. (2019). Salicylic acid: biosynthesis, perception, and contributions to plant immunity. Curr. Opin. Plant Biol. 50, 29-36. doi: 10. 1016/j.pbi.2019.02.004

Zhou, J.-M., Trifa, Y., Silva, H., Pontier, D., Lam, E., Shah, J., et al. (2000). NPR1 differentially interacts with members of the TGA/OBF family of transcription factors that bind an element of the pr-1 gene required for induction by salicylic acid. Mol. Plant-Microbe Interact. 13, 191-202. doi: 10.1094/MPMI.2000.13.2. 191

Conflict of Interest: ACRD, CV, MM, and FG were employed by the company STAPHYT.

The remaining authors declare that the research was conducted in the absence of any commercial or financial relationships that could be construed as a potential conflict of interest.

Copyright (c) 2020 Verly, Djoman, Rigault, Giraud, Rajjou, Saint-Macary and Dellagi. This is an open-access article distributed under the terms of the Creative Commons Attribution License (CC BY). The use, distribution or reproduction in other forums is permitted, provided the original author(s) and the copyright owner(s) are credited and that the original publication in this journal is cited, in accordance with accepted academic practice. No use, distribution or reproduction is permitted which does not comply with these terms. 